\title{
Biological therapies for the treatment of juvenile idiopathic arthritis: Lessons from the adult and pediatric experiences
}

\author{
Matthew L Stoll \\ Alisa C Gotte \\ Department of Pediatrics, Division \\ of Rheumatology, UT Southwestern \\ Medical Center, Dallas, TX, USA
}

\begin{abstract}
Biologics have advanced the therapy of adult and pediatric arthritis. They have been linked to rare serious adverse outcomes, but the actual risk of these events is controversial in adults, and largely unknown in pediatrics. Because of the paucity of safety and efficacy data in children, pediatric rheumatologists often rely on the adult literature. Herein, we reviewed the adult and pediatric literature on five classes of medicines: Tumor necrosis factor (TNF) inhibitors, anakinra, rituximab, abatacept, and tocilizumab. For efficacy, we reviewed randomized controlled studies in adults, but did include lesser qualities of evidence for pediatrics. For safety, we utilized prospective and retrospective studies, rarely including reports from other inflammatory conditions. The review included studies on rheumatoid arthritis and spondyloarthritis, as well as juvenile idiopathic arthritis. Overall, we found that the TNF inhibitors have generally been found safe and effective in adult and pediatric use, although risks of infections and other adverse events are discussed. Anakinra, rituximab, abatacept, and tocilizumab have also shown positive results in adult trials, but there is minimal pediatric data published with the exception of small studies involving the subgroup of children with systemic onset juvenile idiopathic arthritis, in whom anakinra and tocilizumab may be effective therapies.
\end{abstract}

Keywords: juvenile idiopathic arthritis, biologics, rheumatoid arthritis

\section{Introduction}

Juvenile idiopathic arthritis (JIA) affects between 1:1000-1:2000 children (Manners and Bower 2002). This condition is heterogeneous, divided into several subtypes based upon various clinical, laboratory, and epidemiological features (Petty et al 2004). Untreated, JIA can last well into adulthood, causing significant long-term functional impairment (Minden et al 2000).

The last 10-15 years have witnessed an explosion in the development and application of medicines designed to target specific cytokines or cell surface receptors, therapies broadly referred to as biologics (Siddiqui 2007). In addition, etanercept, adalimumab, and abatacept all have indications for JIA; Table 1 summarizes the biologics currently used or under consideration for JIA. Multiple biologics have been approved for use in rheumatoid arthritis (RA) as well as the spondyloarthropathies (SpA), including ankylosing spondylitis (AS) and psoriatic arthritis (PsA) (Siddiqui 2007). In addition, etanercept, adalimumab, and abatacept all have indications for JIA. Table 1 summarizes the biologics currently used or under consideration for use in JIA.

This article is intended as a comprehensive review on the potential role of biologic therapy in pediatric arthritis. In contrast to previous review articles on this topic (Hashkes and Laxer 2006; Lovell 2006; Gartlehner et al 2008), however, we have elected to include data from adult studies as well. With respect to effectiveness data, 
Table I Biologics used in adult and pediatric arthritis. Adapted from Gartlehner and colleagues (2008)

\begin{tabular}{|c|c|c|c|c|c|}
\hline Generic name & US trade name & Mechanism of action & Usual dosing & FDA-approved uses & Common JIA usage \\
\hline Abatacept & Orencia $^{\circledR}$ & $\begin{array}{l}\text { T-cell costimulation } \\
\text { inhibitor }\end{array}$ & $\begin{array}{l}10 \text { mg/kg (max } 1000 \text { mg) } \\
\text { IV monthly }\end{array}$ & RA, polyarticular JIA & None \\
\hline Adalimumab & Humira $^{\circledR}$ & TNF inhibitor & $\begin{array}{l}24 \mathrm{mg} / \mathrm{m}^{2}(\mathrm{max} 40 \mathrm{mg}) \\
\mathrm{SC} \text { every other week }\end{array}$ & $\begin{array}{l}\text { RA, PsA, AS, Crohn's, } \\
\text { JIA }\end{array}$ & $\begin{array}{l}\text { Polyarticular course } \\
\text { JIA, uveitis }\end{array}$ \\
\hline Anakinra & Kineret $^{\circledR}$ & IL-I receptor antagonist & $\begin{array}{l}\mathrm{I}-2 \mathrm{mg} / \mathrm{kg}(\max 100 \mathrm{mg}) \\
\mathrm{SC} \text { daily }\end{array}$ & RA & SOJIA \\
\hline Etanercept & Enbrel $^{\circledR}$ & TNF inhibitor & $\begin{array}{l}0.4 \mathrm{mg} / \mathrm{m}^{2}(\max 25 \mathrm{mg}) \\
\mathrm{SC} \text { twice weekly }\end{array}$ & $\begin{array}{l}\text { RA, polyarticular JIA } \\
\text { (age 2-I7), PsA, AS, } \\
\text { plaque psoriasis }\end{array}$ & $\begin{array}{l}\text { Polyarticular course } \\
\text { JIA }\end{array}$ \\
\hline Infliximab & Remicade $^{\circledR}$ & TNF inhibitor & $3-10 \mathrm{mg} / \mathrm{kg}$ IV monthly & $\begin{array}{l}\text { RA, Crohn's, AS, PsA, } \\
\text { plaque psoriasis, } \\
\text { ulcerative colitis }\end{array}$ & $\begin{array}{l}\text { Polyarticular course } \\
\text { JIA, uveitis }\end{array}$ \\
\hline Rituximab & Rituxan $^{\circledR}$ & B-cell depletion & $\begin{array}{l}\text { I000 mg IV x two doses } \\
\text { two weeks apart }\end{array}$ & $\begin{array}{l}\text { B-cell non-Hodgkin's } \\
\text { lymphoma, RA } \\
\text { refractory to TNF } \\
\text { inhibitors }\end{array}$ & $\begin{array}{l}\text { RF-positive polyarticular } \\
\text { JIA (rarely used) }\end{array}$ \\
\hline Tocilizumab & $\mathrm{N} / \mathrm{A}$ & IL-6 receptor antibody & $\begin{array}{l}2-8 \mathrm{mg} / \mathrm{kg} \text { every two } \\
\text { weeks }\end{array}$ & None & SOJIA ${ }^{c}$ \\
\hline
\end{tabular}

Abbreviations: AS, anklylosing spondylitis; IL, interleukin; IV, intravenous; JIA, juvenile idiopathic arthritis; N/A, not applicable; PsA, psoriatic arthritis; RA, rheumatoid arthritis; RF, rheumatoid factor; SC, subcutaneous; SOJIA, systemic onset juvenile idiopathic arthritis; TNF, tumor necrosis factor.

Notes: ${ }^{\mathrm{T}}$ The first doses are given on days I, I5, and 29 , followed by monthly; ${ }^{\mathrm{b}} \mathrm{Can}$ be combined into a single weekly dose; ${ }^{\mathrm{c} A v a i l a b l e}$ only on experimental basis in United States.

this decision is justified in part by the likely genetic and mechanistic similarities between certain categories of JIA and their adult counterparts, such as RF-positive polyarticular JIA and RA; and enthesitis-related arthritis (ERA) and adult SpA (Ferucci et al 2005; Gensler and Davis 2006; Saxena et al 2006). In light of these similarities and the paucity of randomized trials in pediatrics, adult data is often the basis for our treatment decisions. Indeed, it was recently argued that the resources of pediatric rheumatology, both financial and patient, are limited and might be put to better use than duplicating studies of therapies already proven successful in adults (Lehman 2007). We have therefore incorporated data from randomized double-blinded placebo-controlled studies from both adult and pediatric populations. Because of the limited numbers of pediatric randomized trials, we have also presented lesser quality data exclusively involving pediatric patients, such as cohort and retrospective studies.

Similarly, safety data from adult patients often has implications in the pediatric population, perhaps even more so than effectiveness data, since the safety of therapy probably does not depend upon the mechanism of the underlying disease. Consequently, pediatric rheumatologists should be aware of the lessons learned from our adult counterparts. We have therefore incorporated safety data from both the adult and pediatric literature from various sources, including randomized trials, registries, other large cohort studies, and case reports. Because of the heterogeneity of JIA, we have included adult safety and efficacy data obtained from both RA and SpA patients.

\section{Tumor necrosis factor inhibitors}

\section{Basic scientific rationale}

A potential role for TNF in the pathogenesis of rheumatoid arthritis was initially reported in the 1980s (Hopkins and Meager 1988), and testing of a monoclonal antibody to TNF was begun in the mid-1990s. At present, there are three anti-TNF therapies available (Figure 1). Etanercept, a fusion protein consisting of the extracellular ligand-binding protein of the human 75-Kd TNF receptor linked to the Fc portion of human IgG1, is approved for RA, JIA (for patients 2-17 years old), PsA, AS, and plaque psoriasis (Zhou 2005). Infliximab, a chimeric monoclonal antibody consisting of a murine immunoglobulin variable region directed against TNF fused with a human IgG1 Fc region, is approved for RA, Crohn's disease, ulcerative colitis, AS, PsA, and plaque psoriasis (Feldmann et al 2004). Adalimumab, a fully humanized monoclonal antibody consisting of a variable region directed against TNF fused with a human $\mathrm{Fc}$ created from a phage display of human components, is approved for use in RA, PsA, AS, JIA, and Crohn's disease (Feldmann et al 2004). As shown in Figure 1, the fusion protein etanercept differs in its mechanism of action from the monoclonal antibodies infliximab and adalimumab; the significance of this difference in the treatment of arthritis and other rheumatological conditions is unclear (Rigby 2007).

\section{Effectiveness}

All told, at least 35 randomized, double-blind, placebocontrolled trials have demonstrated the three TNF inhibitors 

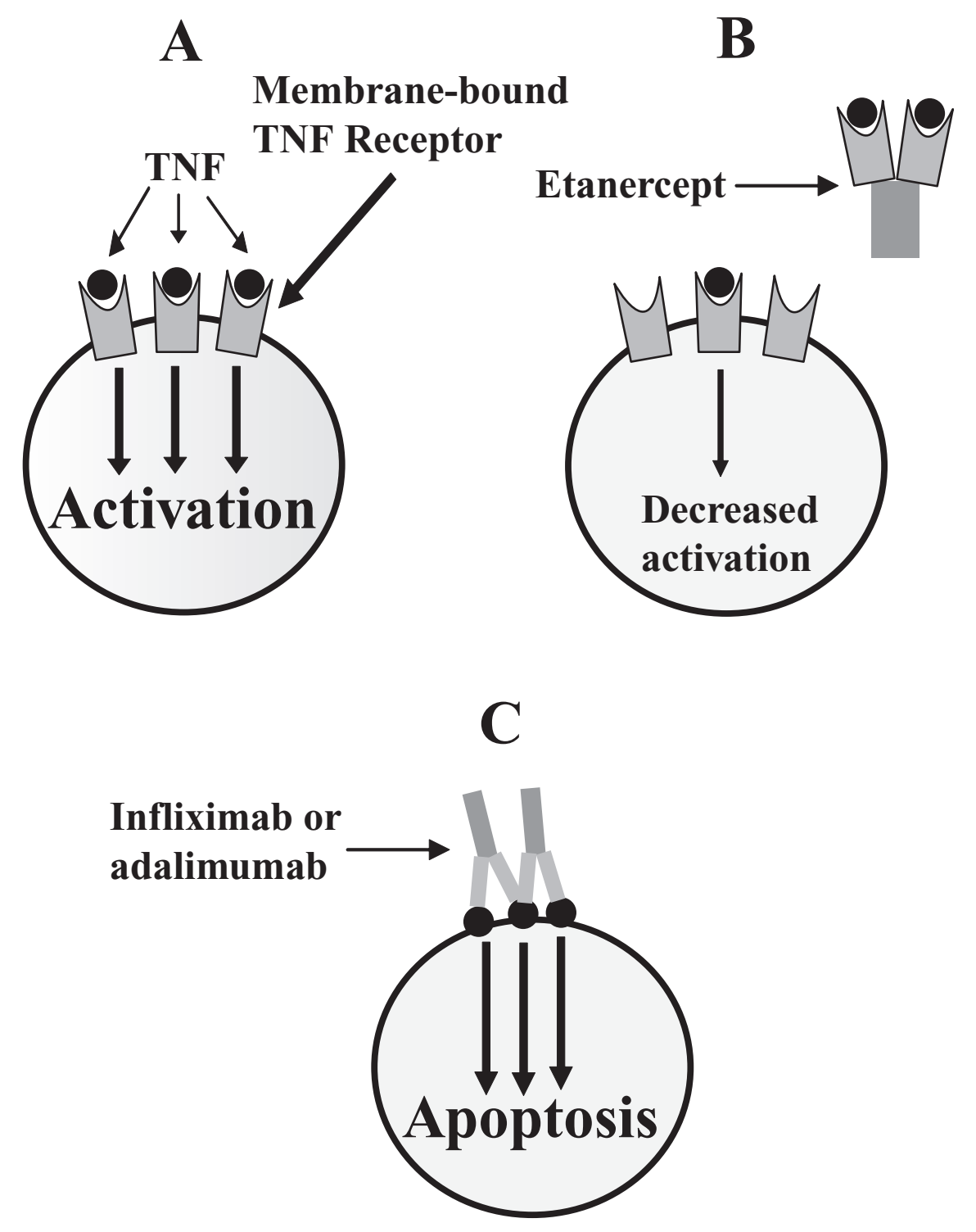

Figure I Mechanism of action of the TNF inhibitors. The binding of soluble TNF to its membrane-bound receptor induces cellular activation and inflammation (A) Soluble TNF receptor fused to human Ig (etanercept) serves as a decoy receptor, binding to soluble TNF and preventing the TNF from binding to its membrane-bound receptor (B) The anti-TNF monoclonal antibodies bind to membrane-bound TNF, inducing apoptosis of cells involved in the inflammatory pathway (C) Adapted from Rigby (2007). Abbreviations: Ig, immunoglobulin;TNF, tumor necrosis factor.

to be effective in the treatment of arthritis, including the spondyloarthropathies, all but one of which involved the adult population (Elliott et al 1994; Rankin et al 1995; Moreland et al 1997; Maini et al 1998; Moreland et al 1999; Weinblatt et al 1999; Kavanaugh et al 2000; Lipsky et al 2000; Lovell et al 2000; Mease et al 2000; Van Den Bosch et al 2002; Brandt et al 2003; Davis et al 2003; Furst et al 2003; van de Putte et al 2003; Weinblatt et al 2003; Calin et al 2004; Keystone et al 2004a, 2004b; Klareskog et al 2004; Lan et al 2004; St Clair et al 2004; Taylor et al 2004; van de Putte et al 2004; Antoni et al 2005a, 2005b; MarzoOrtega et al 2005; Mease et al 2005; Quinn et al 2005; van der
Heijde et al 2005; Abe et al 2006; Breedveld et al 2006; van der Heijde et al 2006b; Westhovens et al 2006; Genovese et al 2007). To our knowledge, no negative studies have been published in the adult population, a record demonstrating the impressive effectiveness of this class of medicines in the management of inflammatory arthritis. Recently, a negative trial was published in pediatrics; this will be discussed in detail below (Ruperto et al 2007).

Several nonrandomized studies have evaluated etanercept in refractory JIA, generally finding it to be safe and effective (Kietz et al 2002; Lahdenne et al 2003; Quartier et al 2003; Henrickson and Reiff 2004; Horneff et al 
2004). In the largest of these studies, the German etanercept registry, 322 children with JIA were followed for a median of 12 months, with significant improvements reported in each of the response criteria studied (swollen and tender joint counts, joints with limited range of motion, morning stiffness, physician and patient global assessment, CHAQ, and ESR), with remission reported in 26\% (Horneff et al 2004). Overall, treatment was well-tolerated, although there were 12 severe adverse events, including one case each of pneumonia requiring mechanical ventilation, thyroid cancer, and demyelination (Horneff et al 2004). Kietz and colleagues (2002) prospectively studied 22 children with polyarticular course JIA for a median of 21 months, finding substantial improvement in clinical and laboratory parameters in this cohort; treatment was welltolerated, with side effects limited to mild injection site reactions (Kietz et al 2002). Importantly, while Kietz and colleagues (2002) and Horneff and colleagues (2004) both reported prolonged duration of effectiveness, a different group reported rapid but nonsustained improvement; for example, ACR-30 scores were reported in 73\% at 3 months, compared with only $39 \%$ at 12 months. In addition, 12 of 61 patients in the latter study discontinued treatment because of severe adverse events, including pancytopenia, psychiatric disorders, uveitis, onset of inflammatory bowel disease, optic neuritis, headaches, vasculitis, and weight gain (Quartier et al 2003).

The first published randomized trial of a TNF inhibitor in JIA involved etanercept. Lovell and colleagues (2000) enrolled 69 children 4-17 years of age with active polyarticular-course disease despite treatment with methotrexate into the initial open-label phase of the trial. After three months, the 51 children in whom improvement was noted were enrolled into the four-month double blind phase, with the endpoint being disease flare or 120 days, whichever occurred first; of these 51 children, 25 were randomized to etanercept, and the remainder received placebo injections. Results at the end of the double-blind phase revealed disease flares occurred in $81 \%$ of placebo-treated children, compared with $28 \%$ of etanercept-treated children ( $p<0.05)$, with median times to flare of 28 and 116 days, respectively ( $p<0.05)$. There were no statistically significant differences in adverse events during the blinded portion of the study, although two etanercepttreated children were hospitalized: one for depression, and the other for gastroenteritis (Lovell et al 2000).

Children who completed the double-blind phase were eligible to enroll into the second open-label phase; 58 children entered into the extension study, and 32 completed four years.
Lovell and colleagues (2006b) reported improvements in all measures of disease activity and decreased corticosteroid usage among the children participating in the extension study, including those who did not complete the four-year study. Etanercept was generally well-tolerated; overall, there were 225 patient-years of follow-up, with 8 serious infections, for a rate of 3 per 100 person-years. There were no lupus-like events, demyelinating lesions, or malignancies (Lovell et al 2006b). Thus, etanercept appears to be safe and effective for longterm use in JIA. However, this study was faulted for bias introduced by the three-month run-in period, as well as for its failure to adjust for baseline differences between the groups, such as older age, longer disease duration, increased RF positivity, and increased corticosteroid usage among the control groups, differences that could bias towards showing an increased effect (Gartlehner et al 2008).

With respect to infliximab, there are several uncontrolled retrospective and prospective studies, beginning with the case report by Elliot and colleagues (Elliott et al 1997; Lahdenne et al 2003; Schmeling and Horneff 2004; Gerloni et al 2005; De Marco et al 2007; Norambuena et al 2007). The three prospective studies generally showed effectiveness among those who tolerated it, although infusion reactions caused frequent discontinuations. For example, Gerloni and colleagues (2005) reported significant improvements in the core measures of disease activity among 24 young adults with persistently active polyarticular JIA after 24 months of therapy, although six of the 24 dropped out ( 5 because of infusion reactions and one because of disease relapse), and 9 others did not complete two years of observation for unstated reasons. Lahdenne and colleagues (2003) enrolled 14 polyarticular children, reporting ACR-75 improvements among six of nine treated with infliximab for one year, although a total of six withdrew within the first eight months: three because of infusion reactions, one with alopecia, one with macrophage activation syndrome, and one because of lack of efficacy (Lahdenne et al 2003). Finally, de Marco and colleagues (2007) treated 78 JIA patients with infliximab for up to three years, finding significant and long-lasting improvements in the majority, but also reporting that 26 discontinued because of adverse events, most commonly infusion reactions (De Marco et al 2007).

The results of a randomized controlled trial of infliximab in JIA were published in 2007. In this study, children with active arthritis were randomized to receive either placebo for 14 weeks, followed by infliximab $6 \mathrm{mg} / \mathrm{kg}$ at weeks 14 , 16,20 , and every 8 weeks thereafter for a total of 44 weeks; or infliximab $3 \mathrm{mg} / \mathrm{kg}$ at weeks $0,2,6$, and 14 , followed by 
placebo at week 16, then $3 \mathrm{mg} / \mathrm{kg}$ again at week 20 and every 8 weeks thereafter. All patients received methotrexate cotherapy throughout the study period. At week 14 , the duration of the placebo-controlled portion of the study, more children in the $3 \mathrm{mg} / \mathrm{kg}$ group achieved an ACR-30 response compared with the placebo group (37 of 58 [63.8\%] vs 29 of 59 [49.2\%]), but this was not statistically significant $(p=0.12)$, so the study failed to achieve its primary aim. Nevertheless, at week 14 , children the infliximab group had significantly fewer joints with active arthritis. At the end of the 52-week study period, there were no significant differences between the two treatment groups in the core set components (Ruperto et al 2007).

Safety analysis from the infliximab study revealed that children in the low-dose infliximab group were more likely to generate anti-infliximab antibodies compared with those in the $6 \mathrm{mg} / \mathrm{kg}$ group, and were also more likely to have infusion reactions. Serious adverse events occurred in 19 of 60 patients over 52 weeks treated with $3 \mathrm{mg} / \mathrm{kg}$ infliximab, 3 of 60 placebo patients over 14 weeks, and 3 of 57 patients over 38 weeks treated with $6 \mathrm{mg} / \mathrm{kg}$ infliximab, so that after adjusting for length of treatment, they were most common in the low-dose infliximab group and least common in the high-dose group. There were six serious infections, including one case of asymptomatic pulmonary tuberculosis, in the infliximab-treated groups compared with two in the placebo patients; the authors did not adjust for length of treatment, but it appears that after doing so, no increased risk associated with drug therapy would be apparent. One placebo patient died of sepsis during the study; one infliximab-treated patient with systemic onset JIA (SOJIA) died during the open-label phase of the study, six months after the final dose, from cardiac complications of the underlying disease. No malignancies were reported (Ruperto et al 2007).

Finally, there is emerging evidence that adalimumab may also be effective in JIA. Biester and colleagues (2007) reported on 16 patients with JIA who had previously failed treatment with conventional DMARDs and other TNF inhibitors, finding a good response in 10, and a mild response in three (Biester et al 2007). In addition, data from a Phase III clinical trial of adalimumab in JIA presented at the 2006 American College of Rheumatology conference, but not yet published, revealed significantly higher clinical responses to the study drug compared with placebo, albeit with 4 unspecified serious adverse events compared with two in the placebo arm (Lovell et al 2006a).

For older children, pediatric dosing of the TNF inhibitors is similar to that used in adult medicine. The initial etanercept trials in adults used doses of $25 \mathrm{mg}$ subcutaneously twice weekly (Brandt et al 2003; Davis et al 2003; Calin et al 2004), while the JIA trial used a dose of $0.4 \mathrm{mg} / \mathrm{kg}$ twice weekly, maximum of $25 \mathrm{mg}$ per dose (Lovell et al 2000). However, because a single $50 \mathrm{mg}$ dose has been shown to be equally effective in adults with rheumatoid arthritis or ankylosing spondylitis, the latter is often used in adult rheumatology (Keystone et al 2004b; van der Heijde et al 2006a). This dose has not been formally studied in pediatrics, but two small case series have shown that it may be equally effective (Kuemmerle-Deschner and Horneff 2007; Prince et al 2007), and many practitioners have altered their practice accordingly. Dosing used in the unpublished adalimumab trial was $24 \mathrm{mg} / \mathrm{m}^{2}$ (Lovell et al 2006a), maximum of $40 \mathrm{mg}$ every other week, the standard adult dose (Breedveld et al 2006). Pediatric and adult dosing of infliximab is typically $3-10 \mathrm{mg} / \mathrm{kg}$ at weeks 0,2 , and 6 and q4-8 weeks thereafter (Lahdenne et al 2003; St Clair et al 2004; De Marco et al 2007; Ruperto et al 2007).

The role of methotrexate co-therapy in pediatric patients using TNF inhibitors is uncertain. Randomized trials among adult patients with RA have shown that all three TNF inhibitors are more effective as co-therapy with methotrexate than they are as mono-therapy (Maini et al 1998; Klareskog et al 2004; Breedveld et al 2006). In the etanercept JIA trial, methotrexate was discontinued at the onset of the trial in all patients as per protocol, so no comparisons were available from this study, while in the infliximab trial, all patients received methotrexate (Lovell et al 2000; Ruperto et al 2007). However, data from the German JIA etanercept registry revealed that patients treated with etanercept and methotrexate in combination, compared with those treated with etanercept alone, were more likely to achieve complete remission ( $29 \%$ vs $14 \%, p=0.07$ ) (Horneff et al 2004). Regarding safety, there are advantages to combining infliximab with methotrexate or other disease-modifying anti-rheumatic drugs (DMARDs); combination therapy appears to protect against the development of anti-infliximab antibodies, which have the unfortunate effects of inducing potentially dangerous infusion reactions and lessening the effectiveness of the therapy (Cheifetz and Mayer 2005; Bendtzen et al 2006). In practice, therefore, many pediatric practitioners use methotrexate as co-therapy with TNF agents in the treatment of RA and JIA, particularly when administering infliximab.

The usefulness of methotrexate co-therapy in SpA remains unknown, as no trials have compared TNF inhibitors alone with TNF inhibitors plus conventional DMARDs (Braun et al 2006). There is retrospective data, however. 
In a retrospective study of infliximab-treated patients with inflammatory arthritis, Kapetanovic and colleagues (2006) reported that absence of DMARD co-therapy was a risk factor for infusion reactions in RA, but not $\mathrm{SpA}$, patients. However, there were only $76 \mathrm{SpA}$ patients, and the negative findings in this group may have been due to a lack of statistical power, since 7 of 10 patients with infusion reactions were using infliximab mono-therapy, while such patients constituted only $41 \%$ of all infliximab-treated SpA patients (Kapetanovic et al 2006). In addition, data in Crohn's disease suggests that methotrexate can reduce the immunogenicity of infliximab therapy (Baert et al 2003). Thus, when initiating infliximab therapy in SpA patients, some practitioners will prescribe lowdose methotrexate therapy with the primary aim of preventing infusion reactions, regardless of whether the added therapy will have an additive treatment effect. However, methotrexate co-therapy is not routinely used with etanercept.

Enthesitis-related arthritis (ERA) is a subtype of JIA that has clinical and genetic features similar to the adult spondyloarthropathies (Burgos-Vargas et al 2002a). Uncontrolled studies have demonstrated TNF inhibition to be effective for this particular sub-group (Henrickson and Reiff 2004; Tse et al 2005). For example, Henrickson and Reiff (2004) demonstrated effectiveness in 8 children with ERA (age 8-16 years) treated with etanercept for one year in one patient and in two years in seven others. Tse and colleagues (2005) reported a good response in 10 children followed for one year (Tse et al 2005). Finally, Burgos-Vargas and colleagues (2007) presented data at the 2007 ACR conference of a randomized study of 26 children with ERA favoring infliximab over placebo therapy. This parallels the success of TNF inhibition in adult SpA (Mease et al 2000; Van Den Bosch et al 2002; Brandt et al 2003; Davis et al 2003; Calin et al 2004; Antoni et al 2005a, 2005b; MarzoOrtega et al 2005; Mease et al 2005; van der Heijde et al 2005, 2006a, 2006b; Genovese et al 2007). Importantly, adults with axial arthritis have generally demonstrated a poor response to conventional DMARDs, and an international consensus group recommended that TNF inhibitors be used as first line therapy for patients with axial disease (Sampaio-Barros et al 2000; Braun et al 2006; Chen and Liu 2006; Haibel et al 2007). Although two studies of children with juvenile SpA have demonstrated modest benefit of sulfasalazine therapy, neither of them differentiated those with axial symptoms from those with peripheral disease (Huang and Chen 1998; Burgos-Vargas et al $2002 \mathrm{~b}$ ), and there is no data showing that traditional DMARDs are effective in the axial disease of ERA. Thus, our practice is to follow the adult spondyloarthritis guidelines and use TNF inhibitors as first-line therapy, bypassing the conventional
DMARDs. As noted above, however, when using infliximab, we may use methotrexate as co-therapy to decrease the risk of infusion reactions.

Although TNF inhibitors have been generally effective in polyarticular JIA and ERA, they have been less so in SOJIA (Billiau et al 2002; Russo et al 2002; Katsicas and Russo 2005; Kimura et al 2005). The first TNF inhibitor to be reported for treatment of this illness was etanercept. Kimura and colleagues (2005) reviewed 82 patients treated with etanercept, finding a good or excellent response in $46 \%$ and a poor response in $45 \%$ (Kimura et al 2005). Likewise, Russo and colleagues (2002) reported their experience with 15 children with SOJIA; 14 of them did enjoy an initial response, but relapses were observed in nine, particularly when the doses of concomitant steroids and methotrexate were lowered (Russo et al 2002). Two observational studies comparing etanercept in children with different subtypes of JIA have found that the drug is less effective in children with systemic-onset disease compared with the other JIA subtypes, as did the randomized trial (Lovell et al 2000; Quartier et al 2003; Horneff et al 2004). Infliximab as well has generally been unsatisfying, particularly with respect to the systemic symptoms (Billiau et al 2002; Katsicas and Russo 2005). There is no data comparing the two, although our experience has been that infliximab may be more effective. However, neither has been shown to be particularly effective, and as will be discussed below, therapies targeting interleukin-1 and interleukin-6 have generally shown more promise.

It has long been understood that a dangerous complication of pediatric arthritis is uveitis (Schaller et al 1969). Although initial case reports did show limited success with treatment with etanercept (Reiff et al 2001), subsequent studies have not borne this out (Schmeling and Horneff 2005; Smith et al 2005; Saurenmann et al 2006). Indeed, a small controlled study enrolling 12 pediatric patients with uveitis found that the seven who received etanercept had no better response than the five who received placebo (improvement was noted in three of seven etanercept-treated patients, versus two of five placebo patients) (Smith et al 2005). In contrast, infliximab has been reported to be effective for uveitis in several case reports (Richards et al 2005; Kahn et al 2006; Rajaraman et al 2006), with small comparative studies demonstrating it to be more effective than etanercept (Saurenmann et al 2006; Foeldvari et al 2007; Tynjala et al 2007). Foeldvari and colleagues (2007) surveyed the international pediatric rheumatology community, obtaining responses from 15 centers in which TNF inhibitors were used for this indication. The 15 centers entered 47 patients into this retrospective analysis, reporting 
a good / moderate / poor response of $68 \% / 32 \% / 0 \%$ for infliximab, versus $47 \% / 15 \% / 38 \%$ for etanercept, a statistically significant difference $(p<0.05)$. In this study, only three children used adalimumab, all of whom demonstrated a good response (Foeldvari et al 2007). Likewise, Tynjala and colleagues (2007) reported on their experiences in the management of pediatric JIA-associated uveitis at a single center, finding treatment failure in 54\% of etanercept-treated patients versus $19 \%$ in the infliximab group (Tynjala et al 2007). Lastly, Saurenmann and colleagues (2006) performed a retrospective study of 21 children treated with TNF inhibitors for uveitis, finding that infliximab was significantly more likely to induce a moderate or good response compared with etanercept (Saurenmann et al 2006). In the randomized trial of infliximab in JIA, uveitis was an exclusion criteria, so its use was not evaluated in this population (Ruperto et al 2007). Two recent case series have found that adalimumab was effective in the management of pediatric uveitis (Vazquez-Cobian et al 2006; Biester et al 2007). Biester and colleagues (2007) reported that 16 of 18 children with uveitis responded well to adalimumab, while Vazquez-Cobian and colleagues (2006) reported decreased ocular inflammation in 12/14 children, with improved vision and decreased use of topical steroids in the other two patients. Thus, treatment with one of the TNF inhibitor monoclonal antibodies has become the standard of care for children with uveitis who failed DMARD therapy.

\section{Safety}

Perhaps the most feared complication of TNF inhibitors is infection. There have been a considerable number of case reports and case series describing serious or opportunistic infections, including Pneumocystis jivoreci and Mycobacterium tuberculosis (MTB), among adult and pediatric patients taking TNF inhibitors (Gomez-Reino et al 2003; Armbrust et al 2004; Kinder et al 2004; Tubach et al 2006; Kaur and Mahl 2007; Kesteman et al 2007), and national surveillance data from Spain confirmed an increased risk of MTB relative to the background rate associated with RA (Gomez-Reino et al 2003; Kesteman et al 2007). Various groups internationally have established treatment guidelines regarding the risk of MTB, requiring all patients treated with TNF inhibitors to receive a PPD in advance of therapy, and those with positive tests or historical or clinical signs of MTB treated for the infection prior to initiation of TNF inhibitor therapy (Furst et al 2002; Mariette and Salmon 2003; BTS 2005). Fortunately, these recommendations have been effective in reducing the risk of tuberculosis in RA patients treated with TNF inhibitors (Carmona et al 2005).
Although there is a general recognition that TNF inhibitors can predispose to infectious complications, the magnitude of the risk is unclear. They have been generally well tolerated during the randomized trials, with few showing statistically significant increases in infections as compared with the placebo arm. Specifically, of the 36 trials referenced above, 34 reported safety data, and only two demonstrated a statistically significant increase in serious infections (generally defined as those which were life-threatening or resulted in hospitalizations) in the treatment versus the control arms (Keystone et al 2004a; St Clair et al 2004) (Table 2). However, others revealed nonsignificant increases in infections in the drug arm (van de Putte et al 2004; Westhovens et al 2006), and a meta-analysis published in 2006 limited to the two anti-TNF monoclonal antibodies and to RA trials did find an overall increased risk of serious infections (Bongartz et al 2006). This study has been criticized on methodological grounds for several reasons, including its exclusion of etanercept and its failure to take into account the longer duration of follow-up in the drug versus control arms in several of the studies (Dixon and Silman 2006). In addition, the definition of serious infections used in the varying trials was heterogeneous, and some of the patients may not have had infections that all clinicians would consider serious or life-threatening, such as bronchitis, community-acquired pneumonia, urinary tract infection, or cellulitis (Bongartz et al 2006). Thus, the data from the randomized controlled studies is suggestive, but not definitive, of an increased overall infection risk.

Important limitations of randomized double-blinded placebo-controlled trials, particularly insofar as interpretation of safety data is concerned, include the small number of patients studied, the relatively short duration of follow-up, and the exclusion of patient who may be at increased risk of complications (Pincus and Stein 1997) Indeed, the percentage of patients in daily practice who would qualify for a randomized trial may be as low as $21 \%-33 \%$, reflecting both lower disease activity and higher comorbidities in the excluded population (Zink et al 2006). Thus, large cohort data has been used to further evaluate the risk of TNF inhibitors in everyday practice. An important caveat of these studies is that TNF inhibitors are obviously preferentially used to treat patients with active disease, which is itself a risk factor for infection (Doran et al 2002), thus it is essential that cohort studies adjust for such potential confounding factors. In addition, knowledge of a patient's treatment status may affect a physician's management of a possible or diagnosed infection. Despite these limitations, large, comparative observational studies have made important contributions to our 
Table 2 Summary of TNF inhibitor trials in inflammatory arthritis

\begin{tabular}{|c|c|c|c|c|c|c|c|c|c|}
\hline \multirow[t]{2}{*}{ Source } & \multirow[t]{2}{*}{ Disease } & \multirow[t]{2}{*}{ Study drug } & \multirow{2}{*}{$\begin{array}{l}\text { Study } \\
\text { duration } \\
\text { (weeks) }\end{array}$} & \multirow[t]{2}{*}{$\mathbf{n}$} & \multicolumn{2}{|l|}{ Placebo } & \multirow[t]{2}{*}{$\mathbf{n}$} & \multicolumn{2}{|l|}{ Study drug } \\
\hline & & & & & $\begin{array}{l}\text { Serious } \\
\text { infections }\end{array}$ & $\begin{array}{l}\text { Hematological } \\
\text { malignancies }\end{array}$ & & $\begin{array}{l}\text { Serious } \\
\text { infections }\end{array}$ & $\begin{array}{l}\text { Hematological } \\
\text { malignancies }\end{array}$ \\
\hline (Elliott et al 1994) & RA & INFL & 4 & 24 & 0 & 0 & 49 & I & 0 \\
\hline (Rankin et al I995) & RA & INFL & $1-4^{a}$ & 12 & 0 & 0 & 24 & 0 & 0 \\
\hline (Moreland et al 1997) & RA & ETAN & 12 & 44 & 0 & 0 & 136 & 0 & 0 \\
\hline (Maini et al I998) & RA & INFL & 26 & 14 & 0 & 0 & 87 & 2 & 0 \\
\hline (Moreland et al 1999) & RA & ETAN & 24 & 80 & I & 0 & 134 & 0 & 0 \\
\hline (Weinblatt et al 1999) & RA & ETAN & 24 & 30 & 0 & 0 & 59 & I & 0 \\
\hline (Kavanaugh et al 2000) & RA & INFL & 12 & 7 & I & 0 & 21 & $\leq 2^{b}$ & 0 \\
\hline $\begin{array}{l}\text { (Lipsky et al 2000) } \\
\text { (ATTRACT) }\end{array}$ & RA & INFL & 54 & 88 & 7 & 0 & 340 & 21 & 1 \\
\hline (Lovell et al 2000) & JIA & ETAN & 16 & 26 & 0 & 0 & 25 & 1 & 0 \\
\hline (Mease et al 2000) & PsA & ETAN & 12 & 30 & 0 & 0 & 30 & 0 & 0 \\
\hline (Van Den Bosch et al 2002) & SpA & INFL & 12 & 20 & 0 & 0 & 20 & 2 & 0 \\
\hline (Brandt et al 2003) & AS & ETAN & $6^{a}$ & 17 & 0 & 0 & 16 & 0 & 0 \\
\hline (Davis et al 2003) & AS & ETAN & 24 & 139 & I & 0 & 138 & 2 & 0 \\
\hline (Furst et al 2003) (STAR) & RA & ADAL & 24 & 318 & 6 & 0 & 318 & 4 & $I^{d}$ \\
\hline (van de Putte et al 2003) & RA & ADAL & 12 & 70 & 0 & 0 & 214 & 4 & 0 \\
\hline $\begin{array}{l}\text { (Weinblatt et al 2003) } \\
\text { (ARMADA) }\end{array}$ & RA & ADAL & 24 & 62 & 0 & 0 & 209 & 2 & 0 \\
\hline (Calin et al 2004) & AS & ETAN & 12 & 39 & 0 & 0 & 45 & 0 & 0 \\
\hline (Keystone et al 2004a) & RA & ADAL & 52 & 200 & I & 0 & 419 & $16^{c}$ & 1 \\
\hline (Keystone et al 2004b) & RA & ETAN & $8^{\mathrm{a}}$ & 53 & 0 & 0 & 367 & $5^{e}$ & 0 \\
\hline $\begin{array}{l}\text { (Klareskog et al 2004) } \\
\text { (TEMPO) }\end{array}$ & RA & ETAN & 24 & 228 & 10 & 0 & 456 & 20 & 0 \\
\hline (Lan et al 2004) & RA & ETAN & 12 & 29 & 0 & 0 & 29 & 1 & 0 \\
\hline (St Clair et al 2004) & RA & INFL & 54 & 282 & 6 & 0 & 722 & $40^{c}$ & I \\
\hline (Taylor et al 2004) & RA & INFL & 54 & 12 & $\begin{array}{l}\text { No safety } \\
\text { data }\end{array}$ & & 12 & No safety data & \\
\hline (van de Putte et al 2004) & RA & ADAL & 26 & 110 & 0 & 0 & 434 & 10 & 0 \\
\hline $\begin{array}{l}\text { (Antoni et al 2005b) } \\
\text { (IMPACT) }\end{array}$ & PsA & INFL & $16^{\mathrm{a}}$ & 52 & 0 & 0 & 52 & 1 & 0 \\
\hline $\begin{array}{l}\text { (Antoni et al 2005a) } \\
\text { (IMPACT II) }\end{array}$ & PsA & INFL & 24 & 100 & NS & 0 & 100 & NS & 0 \\
\hline (Mease et al 2005) (ADEPT) & PsA & ADAL & 24 & 162 & 1 & 0 & $|5|$ & 1 & 0 \\
\hline (Marzo-Ortega et al 2005) & AS & INFL & 30 & 14 & 0 & 0 & 28 & 0 & 0 \\
\hline (Quinn et al 2005) & RA & INFL & 52 & 10 & 0 & 0 & 10 & 0 & 0 \\
\hline $\begin{array}{l}\text { (van der Heijde et al 2005) } \\
\text { (ASSERT) }\end{array}$ & AS & INFL & 24 & 78 & 0 & 0 & 201 & 2 & 0 \\
\hline (Abe et al 2006) & RA & INFL & $14^{a}$ & 47 & I & 0 & 100 & 5 & 0 \\
\hline $\begin{array}{l}\text { (Breedveld et al 2006) } \\
\text { (PREMIER) }\end{array}$ & RA & ADAL & 104 & 257 & 7 & I & 542 & 12 & 1 \\
\hline $\begin{array}{l}\text { (van der Heijde et al 2006) } \\
\text { (TEMPO) }\end{array}$ & AS & ADAL & 24 & 107 & 1 & 0 & 208 & 0 & 0 \\
\hline (Westhovens et al 2006) & RA & INFL & 22 & 363 & 6 & 0 & 721 & 24 & 0 \\
\hline (Genovese et al 2007) & PsA & ADAL & 12 & 49 & I & 0 & 51 & 0 & 0 \\
\hline (Ruperto et al 2007) & JIA & INFL & $52^{f}$ & 60 & 2 & 0 & 60 & 6 & 0 \\
\hline
\end{tabular}

Abbreviations: ADAL, adalimumab; AS, ankylosing spondylitis; ETAN, etanercept; INFL, infliximab; JIA, juvenile idiopathic arthritis; NS, not specified; PsA, psoriatic arthritis; RA, rheumatoid arthritis; SpA, spondyloarthritis.

Notes: aDuration of blinded, placebo-controlled phase of study; ' ${ }^{2}$ Unclear which of any of these were considered serious infections; ' $\mathrm{C}$ tatistically significant ( $\mathrm{P}<0.05$ );

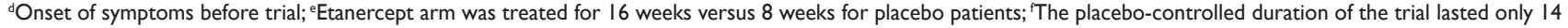
weeks, after which time all patients were treated with study drug for the duration of the 52-week study. 
understanding of the risks of treatment with TNF inhibitors and other therapies. Several studies have identified increased risks of serious infections, including those derived from 1459 patients in the German RA registry (Listing et al 2005); 23,733 patients in a Quebec cohort (Bernatsky et al 2007); 5,326 US patients identified through Medicare claims (Curtis et al 2007); and two separate single-center chart reviews comparing individual patients before and after initiation of TNF inhibitor use (Kroesen et al 2003; Salliot et al 2007). In contrast, three studies failed to show an increased infection risk: these were the British registry containing 8973 RA patients (Dixon et al 2006); a cohort of 16,788 patients enrolled in the National Data Bank for Rheumatic Diseases (which was limited to hospitalizations for pneumonia) (Wolfe et al 2006); and a population of elderly Medicare patients in Pennsylvania (Schneeweiss et al 2007). It is difficult to reconcile these disparate results, although failure to adjust for corticosteroid usage (Listing et al 2005; Bernatsky et al 2007; Curtis et al 2007) may explain some of these findings, since high doses of corticosteroid usage appear to be an important risk factor for infections (Wolfe et al 2006; Bernatsky et al 2007; Salliot et al 2007; Schneeweiss et al 2007). Alternatively, patients with increased risk of infections may not have been considered candidates for TNF inhibitors; infections in these high-risk patients could bias the results towards finding no difference between the DMARD and TNF inhibitor groups (Dixon et al 2006; Curtis et al 2007). Also, failure to incorporate infections that occurred after TNF therapy was discontinued may lead to an underestimation of infection risk, if therapy was discontinued because of symptoms suggestive of infections, but not diagnosed as such at the time of discontinuation; this was found to be the case in post-hoc analysis of the data from the British registry (Dixon et al 2007). In addition, this post-hoc analysis also revealed that limiting the analysis to the first three months of therapy may reveal a sub-population of patients at increased risk of infection; since these patients often discontinue therapy, it follows that that the bulk of the patient-years of follow-up will be comprised of those who tolerated treatment well, thus potentially obscuring a signal (Dixon et al 2007). Indeed, analysis of the Swedish RA registry revealed that the relative risk of an infection leading to hospitalization associated with TNF inhibitor use decreases with each subsequent year of use (Askling et al 2007).

With respect to pediatrics, the etanercept trial did not reveal any significant differences in the incidence of infections (Lovell et al 2000). Data from the four-year followup, as noted above, revealed 8 serious infections over 225 person-years; as described in the manuscript, these included gastroenteritis requiring hospitalization, aseptic meningitis secondary to varicella infection, sepsis, cellulitis requiring hospitalization for IV antibiotics, herpes zoster infection treated with IV acyclovir, appendicitis, a post-operative wound infection, and a dental abscess (Lovell et al 2006b). Likewise, the infliximab trial did not appear to reveal an increased risk of serious infections, after adjusting for different durations of treatment (Ruperto et al 2007). In addition, data from the German etanercept JIA registry consisting of 322 patients with 592 patient-years of follow-up revealed only 20 infectious events, none of which were opportunistic, although several were judged to be serious, including a case of sepsis (Horneff et al 2004). There are no cohort studies comparing pediatric DMARD to TNF inhibitor treated patients; thus, while serious infections have been observed in pediatric patients taking TNF inhibitors, these are uncommon, and contributions from the disease itself or other therapies cannot be excluded.

A second side effect potentially attributed to use of TNF inhibitors is malignancy, particularly hematological (Brown et al 2002; Geborek et al 2005). This perhaps is not unexpected, since the cytokine Tumor Necrosis Factor derived its name from studies from the 1970s in which a factor derived from the serum of bacille Calmette-Guerin (BCG)-immunized mice treated with lipopolysaccharide (LPS) was shown to induce lysis of transplanted tumors (Carswell et al 1975). Numerous studies have reported development of hematological malignancies among patients taking TNF inhibitors (Brown et al 2002), with one report of the lymphoma regressing after TNF inhibitor and coexistent DMARD therapy were withdrawn (Thonhofer et al 2005). In practice, however, the actual risk of hematological malignancies may be limited. Of all the controlled studies referenced above, none of them actually demonstrated a statistically significant increased risk of malignancies, hematological or otherwise; only five revealed any hematological malignancies in the TNF inhibitor-treated patients, and none showed more than one (Lipsky et al 2000; Furst et al 2003; Keystone et al 2004a; St Clair et al 2004; Breedveld et al 2006) (Table 2). The Bongartz meta-analysis did find an increased risk of malignancies among TNF inhibitor users in the RA infliximab and adalimumab trials (Bongartz et al 2006); however, in addition to the criticisms discussed above, it was also noted that the risk of malignancies in the control population was surprisingly low in those studies and may not have reflected the general population (Dixon and Silman 2006). 
In addition, a number of cohort studies have evaluated the risks of malignancies among TNF inhibitor users compared with DMARD users or healthy controls, and the bulk of this data is reassuring. Three large cohort studies, including one in Sweden, one in the US and Canada, and one using data from 19,591 patients in the National Data Bank for Rheumatologic Diseases (NDB), have failed to find an increased risk of lymphoma or other malignancies among patients taking TNF inhibitors (Askling et al 2005a, 2005b; Setoguchi et al 2006; Wolfe and Michaud 2007b). There was one contradictory study from Sweden, which did find an increased risk of lymphoma (Geborek et al 2005); importantly, this was criticized in an accompanying editorial for several reasons, such as incomplete controlling for disease severity and low numbers of lymphoma cases identified altogether, including an unusually low incidence in the control population (Franklin et al 2005). In addition, more recent analysis of the NDB did show a small but statistically significant increased risk of skin cancer (Wolfe and Michaud 2007a). Thus, while active rheumatoid arthritis is a well-known risk factor for lymphoma (Baecklund et al 2006; Franklin et al 2006; Setoguchi et al 2006), it appears that TNF inhibitors may not substantially increase the risk; indeed, it is plausible that to the extent that they are effective in lowering the inflammatory burden, they may even decrease the associated risk of malignancies, although this has note been borne out in studies (Wolfe and Michaud 2004). There may, however, be an increased risk of skin cancers; this will need to be re-evaluated in future studies (Wolfe and Michaud 2007a). Finally, the name TNF itself may be a misnomer; there is more recent data suggesting that the cytokine may actually promote cancer growth at physiological concentrations (Anderson et al 2004).

With respect to pediatrics, neither of the published TNF inhibitor trials revealed any malignancies, including data reported in the four-year open-label follow-up of the etanercept study (Lovell et al 2000, 2006b; Ruperto et al 2007). Horneff and colleagues (2004) did report a case of thyroid cancer in a 19 year-old woman with JIA from their etanercept registry, but to our knowledge, there are no published reports of malignancies among children under 18 years of age that were attributed to TNF inhibitors.

Finally, a handful of additional rare side effects have been reported among TNF inhibitor users: these include episodes of demyelination consistent with multiple sclerosis (Sicotte and Voskuhl 2001; Tanno et al 2006); development of lupus autoantibodies and lupus-like syndromes (Ferraro-Peyret et al 2004; De Bandt et al 2005; Fusconi et al 2007), occasionally associated with frank glomerulonephritis and other serious complications (Mor et al 2005; Chadha and Hernandez 2006); pulmonary nodulosis reversible upon discontinuation of etanercept and concomitant leflunomide therapy (van Ede et al 2007); development of psoriasis, vasculitis, and other autoimmune diseases (Pirard et al 2006; Saint Marcoux and De Bandt 2006; Cohen et al 2007; Prescott et al 2007; Ramos-Casals et al 2007; Verschueren et al 2007); infusion reactions (Crandall and Mackner 2003); and depression (Lovell et al 2000). Even in the pediatric population, cases of optic neuritis, vasculitis, demyelination, drug-induced lupus, and psoriasis have been reported (Lepore et al 2003; Quartier et al 2003; Horneff et al 2004; Peek et al 2006), and as discussed above, discontinuations due to infusion reactions have been reported in $21 \%-22 \%$ of children enrolled in the three open-label infliximab studies (Lahdenne et al 2003; Gerloni et al 2005; De Marco et al 2007).

\section{Summary}

TNF inhibitors have been used to treat arthritis for over 10 years. In general, they have been found to be safe and effective in the adult and pediatric populations (Horneff et al 2004; Keystone 2005; Lovell et al 2006b). One notable exception is the recent infliximab trial in JIA, although it was argued in an accompanying editorial that this likely reflects study design and low patient numbers rather than an actual lack of efficacy in the pediatric population (Lehman 2007). In addition, TNF inhibitors have generally been disappointing in the management of the systemic symptoms of SOJIA (Kimura et al 2005). Among patients with JIA, there is scant data comparing specific TNF inhibitors, with the exception of findings of increased effectiveness of infliximab versus etanercept in the treatment of JIA-associated uveitis (Saurenmann et al 2006; Foeldvari et al 2007; Tynjala et al 2007). Perhaps the most significant risk of therapy in both adults and children is serious infections, including tuberculosis. Fortunately, the adoption of treatment guidelines have mitigated the risk of this particular infection (Carmona et al 2005), but patients still do need to be cautioned about the risks of opportunistic and other serious infection.

\section{Anakinra}

\section{Basic scientific rationale}

Interleukin-1 (IL-1) is a highly inflammatory cytokine which plays an important role in several inflammatory conditions, including RA and SOJIA (Dinarello 1996; Cohen 2004; Pascual et al 2005). The action of IL-1 is regulated by the naturally occurring IL-1 receptor antagonist (IL-1Ra); this protein contains substantial sequence homology to IL-1, 
but rather than causing activation through the IL-1 receptor, serves as a competitive inhibitor to IL-1 and is believed to play an endogenous anti-inflammatory role (Thompson et al 1992). The IL-1Ra was cloned through recombinant technology from human monocytes in 1990 and modified by the addition of a methionine residue at the amino terminus to become the commercially available drug Anakinra (Eisenberg et al 1990; Cohen 2004) (Figure 2). It was initially studied in RA in 1996 and approved for use in RA by the FDA in 2001 (Campion et al 1996; Cohen 2004). Alternative methods for blocking IL-1 are under investigation, but this is beyond the scope of this review.

\section{Effectiveness}

There have been three placebo-controlled trials in RA studying safety and efficacy of anakinra, and a fourth that evaluated safety only, the most frequently used dose being $100 \mathrm{mg}$ daily; in two of the studies, all patients were treated with methotrexate, a third required discontinuation of methotrexate therapy, and the safety trial allowed for individual differences (Bresnihan et al 1998; Cohen et al 2002, 2004; Fleischmann et al 2003). All three trials demonstrated moderate clinical benefit, and improvements in radiographic progression were also documented (Bresnihan et al 1998; Jiang et al 2000; Cohen et al 2002, 2004; Fleischmann et al 2003). However, although there are no randomized head-tohead comparisons of TNF inhibitors with anakinra, a recent review of the existing studies reported that the TNF inhibitor trials generally reported better ACR responses compared with the anakinra trials (Gartlehner et al 2006).

The primary use of anakinra in the JIA population is in the treatment of patients with SOJIA, particularly during the systemic phase of the illness. The effectiveness of anakinra in therapy-resistant SOJIA was first reported in 2004 in an abstract presented at the American College of Rheumatology by Irigoyen and colleagues (2004), who surveyed the pediatric rheumatology community and summarized the experiences of seven patients from five centers, reporting overall improvements in inflammatory markers and arthritis. Verbsky and White (2004) reported their experiences in two patients, both of whom experienced rapid and sustained resolution of symptoms at a dose of $2 \mathrm{mg} / \mathrm{kg}$. Pascual and colleagues (2005) demonstrated prompt and dramatic improvement in both clinical and laboratory parameters in nine patients with refractory SOJIA. In this study, anakinra $(2 \mathrm{mg} / \mathrm{kg}$, maximum $100 \mathrm{mg}$ ) induced resolution of systemic symptoms within the first week of treatment in seven of seven patients, as well as resolution of arthritic symptoms within days to weeks in six of eight patients; the remaining two patients had a partial response of their arthritis (Pascual et al 2005). Likewise, there have been several reports of the use of anakinra in patients with the adult counterpart, adultonset Still's disease (Fitzgerald et al 2005; Vasques Godinho et al 2005; Kalliolias et al 2007; Kotter et al 2007). Virginia Pascual has provided scientific rationale of such therapy, showing upregulation of IL-1 related gene products in children with active SOJIA, trending toward the gene expression levels seen in healthy controls following treatment with anakinra (Pascual et al 2005; Allantaz et al 2007).

Importantly, there have been negative findings as well. Oglivie and colleagues (2007) reported that only one of six children with SOJIA had responded to anakinra. However, it was not clear whether the patients in their study had at the time of the trial mostly systemic or articular features, and our experience has been that anakinra is more effective at treating symptoms in the systemic phase of the disease, compared with the later, articular phase (Pascual et al 2005).

Additionally, Lequerre and colleagues (2008) reported that only five of 20 children with SOJIA treated with 1-2 $\mathrm{mg} / \mathrm{kg}$ /day of anakinra achieved ACR-50 improvements at six months of therapy. In this study, the mean duration of disease was seven years and only $60 \%$ of children had systemic symptoms at the time anakinra therapy was initiated, while the remainder of the children had diffuse and severe arthritis without fever or rash. This contrasts to the more favorable experience of Pascual and colleagues (2005) in which all but two children had systemic features, again suggesting that anakinra may be more effective in the earlier systemic phase of the disease than in the later articular phase.

There is minimal data of anakinra use in other JIA subtypes, none of which has been published to date. An open label study of 82 patients with polyarticular JIA presented only in abstract form, showed an ACR Pediatric 30 response in $58 \%$ of subjects (Ilowite et al 2003), a level which compares unfavorably with that reported in the open-label phase of the etanercept trial ( $~ 80 \%$; Lovell et al 2000). In the double-blind phase of the anakinra trial, there were only small and nonstatistically significant improvements in the anakinra-treated compared with the placebo-treated patients (Ilowite et al 2006).

\section{Safety}

In general, treatment with anakinra, both as monotherapy and in combination with methotrexate, has been shown to be well-tolerated in both adults and children (Bresnihan et al 1998; Cohen et al 2002, 2004; Fleischmann et al 2003; 


\section{A}

\section{Endogenous Interleukin-1 \\ receptor antagonist}

Interleukin-1 $\longrightarrow$

1

T11

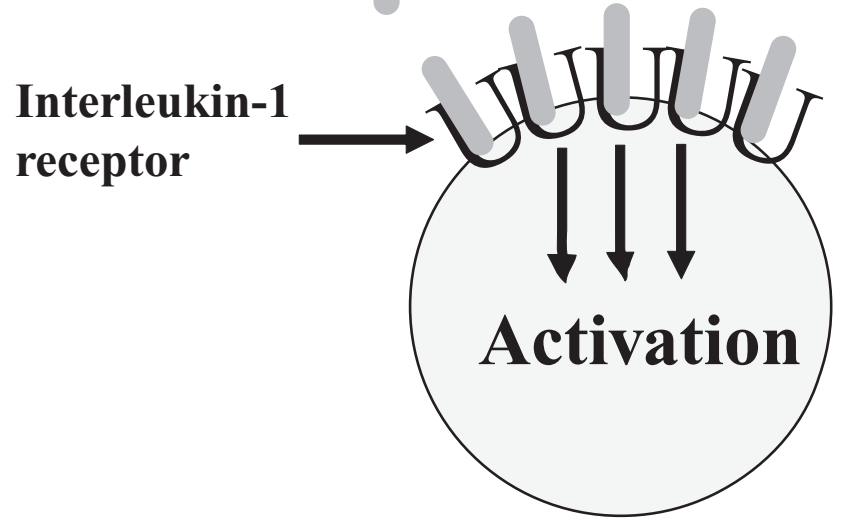

B

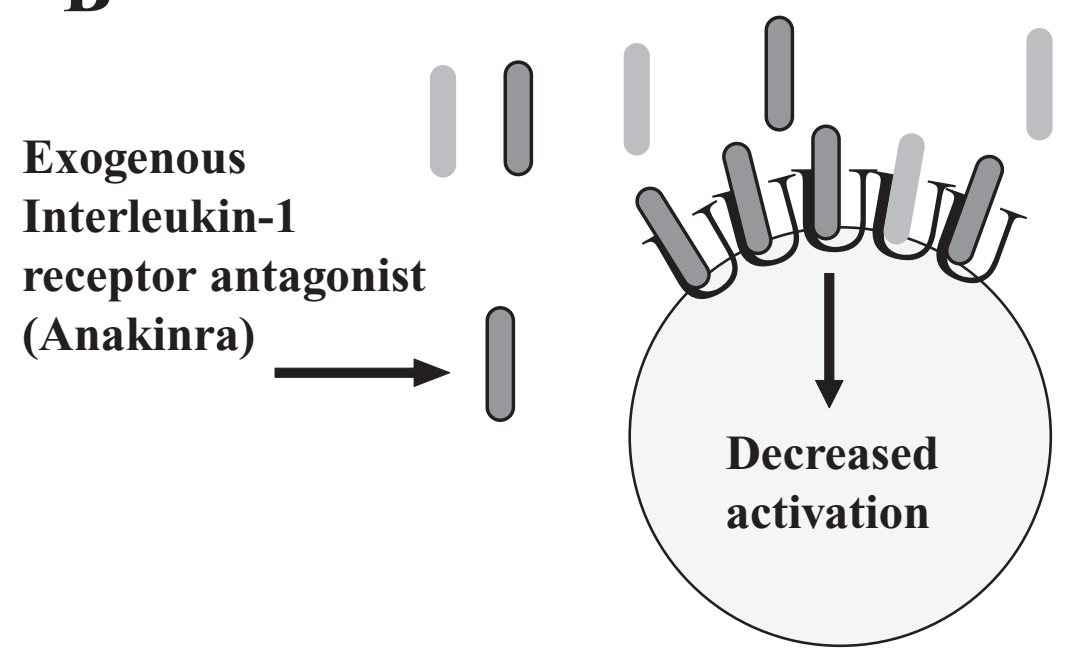

Figure 2 Mechanism of action of anakinra. IL-I binds to its receptor, inducing cellular activation and inflammation (A) Exogenous IL-I receptor antagonist (IL-IRa; Anakinra) competes with IL-I for binding to its receptor but does not induce cellular activation and inflammation (B).

Abbreviation: IL, interleukin.

Pascual et al 2005). Injection site reactions are the adverse effect most often reported and tend to be mild and improve over time (Bresnihan et al 1998; Pascual et al 2005). Patients should be cautioned that the injections themselves can be quite painful, however. In the study published by Pascual and colleagues (2005), one patient with underlying myocardial dysfunction developed two episodes of vomiting and hypotension with anakinra administration. Of the four randomized trials in RA, one did not report any serious infections (Cohen et al 2002), and two others found the risks between the placebo and anakinra arms to be similar (Bresnihan et al 1998; Cohen et al 2004). The largest of the four trials, enrolling 1399 patients, did find an increased risk of serious infections in the anakinra-treated patients $(2.1 \%$ vs $0.4 \%$ ), albeit not statistically significant. Most of the infections consisted of pneumonia or cellulitis; there were no opportunistic infections or cases of TB and none were fatal (Fleischmann et al 2003). A three-year update on this study revealed no significant changes in the rate of adverse events over this time frame (Fleischmann et al 2006). Transient cytopenias have also been reported in study patients, as well as anecdotally (Bresnihan et al 1998; Cohen et al 2002; Quartuccio and De Vita 2007). Finally, anecdotal case reports of cardiac death in a 29 year-old woman with 
adult-onset Still's disease, visceral leishmaniasis in a 9-yearold girl living in an endemic area in southeastern France, tuberculosis reactivation, and multiple-organism sepsis in a 66-year-old RA patient have been documented in patients taking anakinra (Turesson and Riesbeck 2004; Kone-Paut et al 2007; Ruiz et al 2007; Settas et al 2007).

\section{Summary}

Interleukin-1 blockade by anakinra interferes with the pro-inflammatory cascade important in the pathogenesis of chronic arthritis. Although its role in the therapy of RA and polyarticular JIA is undefined, anakinra is generally welltolerated and does appear to be very effective in treating the systemic features of SOJIA (Pascual et al 2005). However, because the pediatric studies were based upon small groups of children, overall pediatric safety data is limited.

\section{Rituximab}

\section{Basic scientific rationale}

Rituximab is a chimeric monoclonal antibody directed against the CD20 surface antigen present on B-cells; it consists of a human IgG1 heavy chain fused to a murine anti-CD20 variable receptor (Grillo-Lopez et al 1999). The CD20 receptor is present on pre- $\mathrm{B}$, naïve, memory, and mature $\mathrm{B}$-cells, but not on plasma cells or stem cells, nor on any other cell lineages, hence the specificity of rituximab for B-cells (Leandro et al 2002). Approved by the FDA for use in CD20+ B-cell lymphomas in 1997, it has since been applied to a variety of autoimmune diseases, perhaps most prominently RA. The FDA approved it for use in RA refractory to TNF inhibitors in 2005 (Smolen et al 2007).

\section{Effectiveness}

Compared with the TNF inhibitors, the amount of safety and effectiveness data for rituximab in RA is limited. There have been two randomized, double-blinded, placebo-controlled trials in RA, both of which showed statistically significant beneficial effects, as did a randomized, placebo-controlled, open-label trial; dosages used in these studies were $500 \mathrm{mg}$ or $1000 \mathrm{mg}$ IV x two doses, two weeks apart (Edwards et al 2004; Cohen et al 2006; Emery et al 2006). Additional important information that has emerged from these trials includes effectiveness of rituximab in patients who have failed TNF inhibitors, increased tolerance of the infusion when patients are pre-medicated with methylprednisolone, and lack of an additive effect with daily oral corticosteroids or with cyclophosphamide infusions (Edwards et al 2004; Cohen et al 2006; Emery et al 2006). In addition, in all three trials, nearly complete B-cell depletion was noted in the rituximab-treated patients, with recovery in two of the studies noted beginning at 16 weeks (Edwards et al 2004; Cohen et al 2006; Emery et al 2006). Additional information about the kinetics of B-cell recovery was obtained by Leandro and colleagues (2006), who observed that B-cell repopulation in a cohort of $24 \mathrm{RA}$ patients took a mean of 8 months and began with a naïve population that eventually matured. Relapses were noted to correlate with increased numbers of mature B-cells in the peripheral blood.

Of substantial relevance to the pediatric patient population, in which the RF-positive population comprises approximately $10 \%$ of children with polyarticular arthritis (Krumrey-Langkammerer and Hafner 2001), two of the trials compared the effectiveness of rituximab therapy in the RF-positive and RF-negative patient populations. One found that the drug was equally effective in both populations, while the other found that there were no differences between RFnegative placebo patients compared with RF-negative study drug patients, although the placebo patients in this study had an unusually high response rate, complicating interpretation of the data (Cohen et al 2006; Emery et al 2006).

To our knowledge, there are only three case reports of rituxumab use in JIA patients, one of whom was an adult at the time of the study. Kuek and colleagues (2006) administered rituximab to a 26-year-old woman with RF-negative polyarticular JIA of 18 years duration, reporting improvements in her functional status and tapering of concomitant corticosteroid therapy (Kuek et al 2006). El-Hallak and colleagues (2007) reported on experiences in 10 children from a single center with various autoimmune conditions treated with rituximab with the lymphoma protocol of $375 \mathrm{mg} / \mathrm{m}^{2}$ weekly $\mathrm{x}$ four weeks, one of whom had polyarticular JIA; her rheumatoid factor status was not reported. This patient did respond well to the therapy (El-Hallak et al 2007). Finally, Dass and colleagues (2007) reported on three patients who developed psoriasis following rituximab use, one of whom was a 17-year-old girl with long-standing B27+, RF-poly-arthritis, who had an unsatisfactory response for six months, before developing psoriasis, pan-uveitis, and Achilles tendon rupture (Dass et al 2007).

\section{Safety}

Most of the safety data for rituximab comes from its use in lymphoma, since over 700,000 patients have received this therapy (Solal-Celigny 2006). The most common side effects are infusion reactions, which are typically mild and tend to resolve after the first dose, although they rarely can be quite severe, resulting in hypotension, bronchospasm, and 
occasionally even death (Kimby 2005; Mohrbacher 2005). Cases of serum sickness, transient cytopenias, and tumor lysis syndrome have also been reported, although the latter is unique to its use in lymphoma (Todd and Helfgott 2007). With respect to infections, the overall oncology experience has been that treated patients have not had more severe or opportunistic infections than would otherwise be expected, given the population, although reactivation of Hepatitis $B$ has been reported (Tsutsumi et al 2005; Solal-Celigny 2006).

None of the three randomized, controlled trials in RA demonstrated a statistically significant increased infection risks, although one did demonstrate a nonsignificant increased risk; none of the studies reported cases of tuberculosis or opportunistic infections (Edwards et al 2004; Cohen et al 2006; Emery et al 2006). Likewise, data from observational studies in adults with RA has generally been reassuring, with mild infusion reactions being the most commonly reported adverse event (Leandro et al 2002; Kneitz et al 2004; Moore et al 2004; Gottenberg et al 2005; Higashida et al 2005; Brulhart et al 2006; Finckh et al 2007; Jois et al 2007; Popa et al 2007). When serious infections have occurred, it was generally unclear whether they were related to the study drug, with the exception that one patient in the study by Popa and colleagues (2007) did develop hypogammaglobulinemia and respiratory infections associated with bronchiectasis. Recently, Dass and colleagues (2007) published a case report of three patients who developed psoriasis during rituximab use. They were a 17-year-old B27-positive, RF-negative JIA patient, a 52-year-old woman with RF-positive RA, and a 26-year-old lupus patient (Dass et al 2007).

As noted above, there is limited published use of this therapy in children with arthritis. There is, however, pediatric data from oncological uses, as well as in other autoimmune diseases, including idiopathic thrombocytopenic purpura and pediatric lupus. Most of these studies have demonstrated safety and effectiveness, with major side effects being infusion reactions and in some cases, serum sickness (Quartier et al 2001; Marks et al 2005; Wang et al 2005; Bennett et al 2006; Parodi et al 2006; El-Hallak et al 2007; Rao et al 2007). Interestingly, serum sickness has not been reported much in RA patients, although Todd and Helfgott (2007) speculated that this may be due to under-reporting caused by confusion with arthritis symptoms. One exception to the generally benign experience with rituximab in pediatric patients was the retrospective study by Willems and colleagues (2006), who reported that of 11 pediatric SLE patients treated with rituximab, 5 had severe adverse events, including two with septicemia and four with significant cytopenias.
Finally, the FDA recently issued an advisory warning about two patients with lupus who developed fatal infection with JC virus, the etiologic agent of progressive multifocal leukoencephalopathy (PML) (2007); there have also been several case reports of PML occurring in oncology patients treated with rituximab, all of whom were also treated with other cytotoxic chemotherapeutic agents (Goldberg et al 2002; Matteucci et al 2002; Steurer et al 2003; Freim Wahl et al 2007). Details of the co-therapies used by the two lupus patients were not released by the FDA.

\section{Summary}

Rituximab is developing a strong effectiveness record in RA, and has been safely used in a variety of other pediatric and adult rheumatological conditions (Quartier et al 2001; Marks et al 2005; Pijpe et al 2005; Wang et al 2005; Bennett et al 2006; Parodi et al 2006; Scheinberg et al 2006; El-Hallak et al 2007; Rao et al 2007; Tanaka et al 2007). A consensus statement released in 2007 recommended use in RF-positive patients who failed TNF inhibitor therapy and who do not have a history of chronic infections. This statement also advised pre-medication with methyl-prednisolone and concomitant use of methotrexate (Smolen et al 2007). However, pediatric data is limited to case reports. Although RA trial data can arguably be extrapolated to RF-positive polyarticular JIA patients, the role of rituximab in RF-negative RA has not been well-defined, and there is minimal data in the spondyloarthropathies. In addition, although rituximab is generally well tolerated, it bears repeating that there have been rare reports of life-threatening infusion reactions and fatal viral infections such as PML (Goldberg et al 2002; Steurer et al 2003; Kimby 2005; 2007; Freim Wahl et al 2007).

\section{Abatacept}

\section{Basic scientific rationale}

The concept behind abatacept was triggered by basic science knowledge of mechanisms involved in T-cell activation. As reviewed by Salomon and Bluestone (2001), T-cell activation generally requires two specific events: the first is presentation of the peptide-MHC complex to the T-cell receptor; the second is co-stimulation through any number of surface receptors present on antigen-presenting cells (APCs) and T-cells, perhaps most importantly the CD80/CD86 on APCs and CD28 on T-cells (Salomon and Bluestone 2001). Cytotoxic T-cell Lymphocyte Antigen-4 (CTLA4) bears structural similarity to CD28, but has much higher affinity for CD80 and CD86 (Bluestone et al 2006). Linsley and colleagues (1991) designed a molecule consisting of 
CTLA4 fused to a modified human Fc region, showing that it inhibited in vitro immune responses; this fusion protein, initially known as CTLA4-Ig, has since been named abatacept (Figure 3). Abatacept was initially studied in transplant rejection, and its initial clinical application was in psoriasis, but it has largely been used in RA, for which purpose it was approved by the FDA in 2005 (Abrams et al 1999; Bluestone et al 2006). Recently, abatacept was also approved for use in polyarticular JIA.

\section{Effectiveness}

Abatacept has been studied in five randomized, placebocontrolled trials in RA (Moreland et al 2002; Kremer et al 2003, 2005, 2006; Genovese et al 2005). In three of the studies, participants were required to use methotrexate as co-therapy (Kremer et al 2003, 2005, 2006); in one trial, patients were required to take any oral DMARD or anakinra as concomitant therapy (Genovese et al 2005), and in one, DMARD therapy was not permitted (Moreland et al 2002). Abatacept was effective in all of the trials, more so at $10 \mathrm{mg} / \mathrm{kg}$ than $2 \mathrm{mg} / \mathrm{kg}$; dosing was at day 1 and 15 , then monthly (Moreland et al 2002; Kremer et al 2003, 2005, 2006; Genovese et al 2005).

Results of an open-label trial in JIA were presented at the 2006 ACR conference, but have not yet been published. In this study, 190 children with JIA were treated with abatacept $10 \mathrm{mg} / \mathrm{kg}$ IV on days 1,15 , and monthly for four months. 123 of the 190 children (65\%) demonstrated ACR-30 responses, and the mean percent reduction in the number of active joints from baseline was 56\%. 20 withdrew from the study, 17 for lack of efficacy, one for adverse events, one for withdrawal

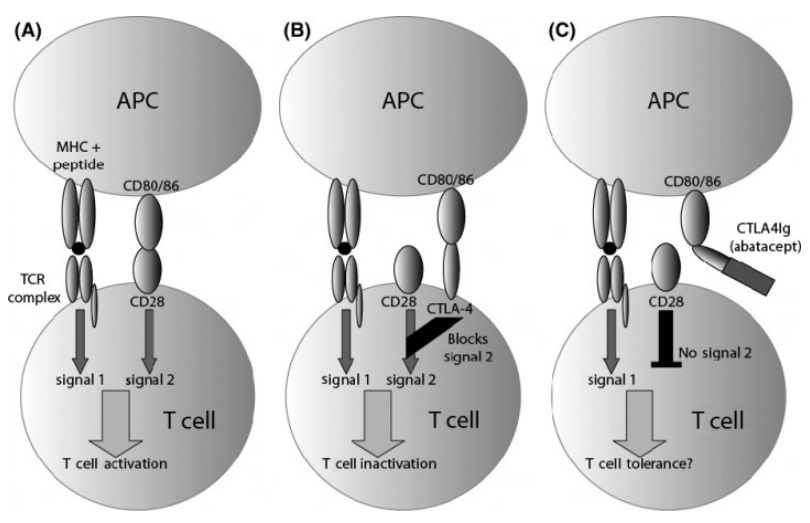

Figure 3 Mechanism of action of abatacept. Under normal circumstances, CD80/86 on antigen-presenting cells (APC) binds to CD28 on T-cells, providing a second signal resulting in T-cell activation following peptide / MHC recognition by the T-cell receptor (A). CTLA4, another receptor on the surface ofT-cells, binds to CD80/86 with increased affinity, transmitting negative signals to the T-cell (B). Soluble CTLA4-Ig (abatacept) binds to CD80/86, preventing it from binding to CD28 (C). Copright (C) 2007 Blackwell Publishing. Reproduced with permission from Todd DJ, Costenbader KH,Weinblatt MT. 2007 Abatacept in the treatment of rheumatoid arthritis. Int J Clin Prac, 61:494-500. of consent, and one for undisclosed reasons (Lovell et al 2006c). Safety data presented in the following year revealed one case of leukemia diagnosed at day 89 of the open-label phase, which the study investigators suspect may have been present prior to enrollment, and a case of varicella encephalitis in a placebo-treated patient in the double-blind phase of the study (Lovell et al 2007).

\section{Safety}

Abatacept has generally been well-tolerated. In three of the trials, severe adverse effects were more common in the placebo arms than in the $10 \mathrm{mg} / \mathrm{kg}$ abatacept arm, generally related to increased disease flares (Moreland et al 2002; Kremer et al 2003, 2005); only one study reported increased severe infections in the abatacept arm, a nonsignificant difference of $3.9 \%$ vs. $2.3 \%$ (Kremer et al 2006). There were no reported cases of tuberculosis or opportunistic infections among patients taking abatacept. In addition, as noted above, preliminary data indicates that abatacept was well-tolerated in JIA patients, although these results have yet to be published (Lovell et al 2007). Abatacept was also well tolerated in an open-label psoriasis study, with no serious infections or other serious adverse events, aside from hospitalization for an asthma flare in a patient with pre-existing asthma (Abrams et al 1999). To our knowledge, there are no published reports of adverse reactions to abatacept, beyond those detailed in the published trials.

\section{Summary}

Abatacept represents a successful transition from basic science research to clinical applications. It appears to be safe and effective in RA, showing success even in patients refractory to TNF inhibitors (Genovese et al 2005). Preliminary data likewise reveals effectiveness in JIA (Lovell et al 2006c). One theoretical concern with abatacept is that CTLA4 transmits negative signals to T-cells, so it could potentially have a pro-inflammatory effect, particularly late in the immune reactions, when negative signaling through CTLA4 dominates (Bluestone et al 2006). Although this theoretical concern has not been borne out by the clinical data, overall experience, particularly in pediatrics, is limited.

\section{Tocilizumab}

\section{Basic scientific rationale}

There is data implicating interleukin-6 (IL-6) in the pathogenesis of RA, with particular genetic polymorphisms conferring an increased risk of the disease and elevated serum levels correlating with disease activity (de Benedetti et al 1991; 
Rooney et al 1995; Fishman et al 1998; Ogilvie et al 2003). Sato and colleagues (1993) constructed a partially humanized monoclonal antibody against the IL-6 receptor, by fusing human IgG1 with a murine CDR directed against the receptor for the human cytokine. This antibody, initially called MRA, is now known as tocilizumab. It has not been approved by the FDA and is generally available in the United States for research purposes only.

\section{Effectiveness}

There have been five randomized, placebo-controlled trials of tocilizumab in RA, with all five showing effectiveness at doses from 4-8 mg/kg, and lesser effects at lower doses (Choy et al 2002; Nishimoto et al 2004, 2007; Maini et al 2006; Smolen et al 2008). In one trial, methotrexate did not demonstrate an additive effect at the therapeutic doses of tocilizumab (Maini et al 2006).

In pediatrics, tocilizumab has largely been studied in SOJIA patients; two open-label studies have been published (Woo et al 2005; Yokota et al 2005). In the study by Woo and colleagues (2005), 18 children with methotrexate-refractory disease for at least 3 months received tocilizumab at doses of $2 \mathrm{mg} / \mathrm{kg}, 4 \mathrm{mg} / \mathrm{kg}$, or $8 \mathrm{mg} / \mathrm{kg}$; follow-up periods were, respectively, 4, 6, or 8 weeks. The efficacy analysis was only based upon 15 children, as there were unspecified protocol violations in three. Overall, treatment led to improvements in clinical and laboratory features, albeit less so at the $2 \mathrm{mg} / \mathrm{kg}$ dose. However, three children required corticosteroid rescue therapy during this short trial, one each at each of the three dosages (Woo et al 2005).

Yokota and colleagues (2005) enrolled 11 children age 2-19 into a dose-escalating trial, in which children received three doses of tocilizumab $2 \mathrm{mg} / \mathrm{kg}$ every two weeks, with the dose increased stepwise to $4 \mathrm{mg} / \mathrm{kg}$ and again to $8 \mathrm{mg}$ / $\mathrm{kg}$ if the lower doses failed to maintain CRP levels below $1.5 \mathrm{mg} / \mathrm{dL}$. Treatment was effective, leading to improvements in multiple parameters, including synovitis, markers of inflammation, fever fluctuations, hemoglobin, and platelet count. Three of the 11 children had the disease stabilized based upon CRP measurements at the $2 \mathrm{mg} / \mathrm{kg}$ dose, five required the $4 \mathrm{mg} / \mathrm{kg}$ dose, and the remainder three were stabilized at the highest dose; all three children who received the $8 \mathrm{mg} / \mathrm{kg}$ dose had ACR-70 responses. No children required rescue therapy (Yokota et al 2005).

Results from a phase III clinical trial in SOJIA were recently published. In this study, 56 children with SOJIA were treated with tocilizumab open-label at $8 \mathrm{mg} / \mathrm{kg}$ every other week for six weeks. 43 met responder criteria and were enrolled into the 12-week long double-blind withdrawal phase; $83 \%$ of placebo patients compared with $20 \%$ of tocilizumab-treated patients withdrew from the study (Yokota et al 2008). An additional study presented at the 2006 ACR conference evaluated the safety and efficacy of tocilizumab in a 12-week long open-label trial of 19 children with polyarticular JIA, showing improvement in clinical parameters; however, of the 19 children, three were hospitalized: two for gastroenteritis and one for sensory disturbance (Imagawa et al 2006).

\section{Safety}

In the open-label pediatric trial published by Woo and colleagues (2005), multiple adverse events were reported: there were 9 infections in total, although the only ones that were considered serious were chicken pox and herpes simplex oral ulcerations. Other serious adverse events were disease flares in two patients and transient pancytopenia in one. In addition, lymphopenia was noted in 15 of 18 patients and transient increases in liver function tests were noted in three (Woo et al 2005). In contrast, in the study by Yokota and colleagues (2005), therapy was well-tolerated, without any serious adverse events; the only potentially infectious adverse events over the 80 days of follow-up were URIs in two children and pustules on the extremities of three. No cytopenias or any other major laboratory abnormalities were reported (Yokota et al 2005). In the phase III study in SOJIA, safety analysis revealed two serious adverse events during the open-label lead in phase, consisting of one anaphylactic reaction and one case of gastrointestinal hemorrhage; two serious adverse events during the double-blind phase, consisting of an EBV infection associated with marked increases in transaminases in a tocilizumab-treated patient and a case of Zoster in a placebo patient; and 13 serious adverse events in an open-label extension phase lasting 48 weeks and enrolling 50 children. Most of these did not appear to be life-threatening, with the exception of an anyphylactic reaction that led to drug discontinuation (Yokota et al 2008). Finally, in the trial of tocilizumab in polyarticular-JIA, three of 19 children were hospitalized over 12 weeks (Imagawa et al 2006). There is a case report of the sudden onset of fatal congestive heart failure and interstitial pneumonitis in a patient with severe chronic infantile neurologic, cutaneous, and articular (CINCA) syndrome who had responded well to tocilizumab for two months prior to his rapid demise; despite the sudden onset of the symptoms, the authors excluded the possibility of an infection causing the patient's deterioration (Matsubara et al 2006). 
Likewise, therapy has generally been tolerated in the adult RA patients, although three of the five studies showed nonstatistically significant increases in serious infections in the drug arm (Nishimoto et al 2004, 2007; Maini et al 2006), while another did not present detailed analysis of the serious infections (Choy et al 2002). There was one reported death, secondary to Epstein-Barr virus reactivation, in the tocilizumab arm of one of the studies (Nishimoto et al 2004).

\section{Summary}

Tocilizumab may have an important role in both RA and SOJIA (Choy et al 2002; Nishimoto et al 2004, 2007; Woo et al 2005; Yokota et al 2005, 2008; Maini et al 2006; Smolen et al 2008); its role in other subtypes of JIA is undetermined. With respect to safety, several randomized controlled trials in RA have shown increases in serious infections in the tocilizumab groups, with one reported death (Nishimoto et al 2004, 2007; Maini et al 2006); importantly, all of these trials were doseranging and therefore had more patients in the tocilizumab arms, but this is clearly an issue that bears further monitoring. In the SOJIA trials, small numbers of enrolled patients preclude definitive conclusions, although occurrences of lymphopenia in one of the trials, as well as three hospitalizations over 12 weeks in another, do suggest a need for caution (Woo et al 2005; Imagawa et al 2006), as does the sudden onset of interstitial pneumonia and congestive heart failure in a CINCA patient whose disease had been brought under good control with therapy (Matsubara et al 2006). Finally, as noted above, tocilicumab has not been approved by the FDA, so would only be available in the United States on an experimental basis.

\section{Combination biological therapy}

Theoretically, there may exist a sound rationale for combining therapy with inhibitors of TNF and other biologics, such as anakinra. The complexity of the cytokine and intracellular signaling pathways makes it unlikely that a single biologic, targeting a single cytokine or cell surface receptor, will be uniformly or completely effective, and indeed, success is measured in improved responses, not complete remission (Isaacs et al 1999; van den Berg 2002). In several different animal models of arthritis, combination therapy with infliximab and anakinra has been significantly more effective than mono-therapy with either agent (Bendele et al 2000; Feige et al 2000; Zwerina et al 2004). Therefore, the possibilities of combination therapy have attracted clinical interest; unfortunately, data to date has not been rewarding.

To our knowledge, Genovese and colleagues (2004) was the first to formally evaluate combination therapy in humans.
In this study, 242 adult RA patients previously untreated with TNF inhibitors or anakinra were randomized to receive etanercept + anakinra placebo, etanercept + anakinra, and halfdose etanercept (25 mg weekly) + anakinra. After 24 weeks, the three groups had generally equivalent responses, with the full-dose etanercept arm actually showing a higher ACR20 response than the etanercept-anakinra combination arm. However, safety analysis revealed significant differences, with both combination arms being associated with significantly increased incidences of serious adverse events and events leading to withdrawal. For example, serious infections were reported in $0 / 80$ etanercept controls, compared with 3/81 half-dosage etanercept - anakinra combination patients and 6/81 full-dosage etanercept - anakinra combination patients; there was one death in the full-dosage combination arm: respiratory insufficiency triggered by pneumonia in a patient with pre-existing pulmonary fibrosis (Genovese et al 2004).

Two recent studies have evaluated combination therapy involving abatacept. Weinblatt and colleagues (2006) randomized 1441 RA patients to abatacept or placebo. An important and unique aspect of this trial is that some of the patients in each group were on background biologic therapy while others were not, thus permitting analysis of the safety of abatacept with or without background biologic therapy. Overall, the abatacept and placebo arms were similar with respect to overall adverse events, serious adverse events, and discontinuations, with a small but statistically nonsignificant increase in serious infections in the patients receiving abatacept $(2.6 \%$ vs. $1.7 \%)$. However, in the subgroup of patients on background biologic therapy, serious infections were reported in 6/103 (5.8\%) of abatacept-treated patients, vs. 1/64 (1.6\%) control patients. Post-hoc efficacy analysis was performed in this safety trial; no evidence of an additive effect was demonstrated (Weinblatt et al 2006).

Finally, Weinblatt and colleagues (2007) randomized 121 patients with an incomplete response to etanercept to receive abatacept or placebo on top of pre-existing etanercept therapy. The abatacept dose in this study was $2 \mathrm{mg} / \mathrm{kg}$ on days 1,15 , and 30 followed by every four weeks for a total of six months, at which point the dose was increased to $10 \mathrm{mg} / \mathrm{kg}$ for another six months. Overall, there were minimal differences in effectiveness between the groups, although the abatacept $2 \mathrm{mg} / \mathrm{kg}$ arm did have an increased ACR-70 response at six months. However, at 12 months, the abatacept-treated patients also showed significantly higher serious adverse events, serious infections, and withdrawals due to adverse events (Weinblatt et al 2007). 
The results of the above studies suggest that practitioners should proceed with extreme caution when combining biologics (Genovese et al 2004; Weinblatt et al 2006, 2007). Importantly, however, none of these studies appeared to include patients treated with rituximab. This is a particularly difficult matter, because the clinical and biological effect of a single course of rituximab can last six months or longer (Edwards et al 2004; Cohen et al 2006; Emery et al 2006; Leandro et al 2006). Genovese and colleagues (2006) presented data at the 2006 ACR conference showing that of 78 patients who received TNF inhibitor therapy following a course of rituximab, the rate of serious infections was 7.62 per 100 person-years after the TNF inhibitors were started, compared with 5.23 per 100 person-years prior to the TNF inhibitor course. These differences were not statistically significant, as they were based upon a total of seven events. However, details of the patient's B-cell levels were not provided, except that they were said to be below the normal limits in all of the patients (Genovese et al 2006). Clearly, more studies are required regarding the safety of biologics following a treatment course of rituximab before any recommendations can be offered.

\section{Summary}

Biologics are routinely used in adult and pediatric arthritis. Overall, they have been remarkably effective, changing the outlook for a generation of patients afflicted with these disorders. Most of the studies on biologics have focused on TNF inhibitors, but emerging evidence, particularly in adults, has suggested that other therapies may be effective as well, even in patients who have failed TNF inhibitors (Genovese et al 2005; Cohen et al 2006). Aside from the TNF inhibitors, there is minimal published pediatric data for these therapies, although anakinra and tocilizumab have both shown promise in the population of children with SOJIA (Pascual et al 2005; Woo et al 2005; Yokota et al 2008) and unpublished data suggests that abatacept may be effective JIA (Lovell et al 2006c).

As expected, safety has emerged as an important consideration in the use of biologic therapy. Overall, the randomized trials have generally shown these therapies to be well-tolerated, but the limitations of these studies, including their small size, relatively short duration of follow-up, and exclusion of patients who may be at greater risk of complications, limits their generalizability, and thus, post-marketing data assumes a particularly important role in their ongoing evaluation (Pincus and Stein 1997). Here again, the biologics have generally been found to be well-tolerated; however, rare and occasionally irreversible or even lethal side effects have emerged in adults and even rarely in children; moreover, the absence of specific safety signals for some of these therapies, particularly in pediatrics, can hardly be taken of evidence of safety and tolerability given the dearth of pediatric data.

A limitation of all biologics is that success is measured in improvement from baseline; remission is rarely a reported outcome in studies. This has tempted rheumatologists to combine two or more biologics, hoping for an additive effect; unfortunately, the limited data published to date has shown minimal benefit with increased harms from this approach (Genovese et al 2004; Weinblatt et al 2006, 2007). Potential risks or benefits of biologics use following a course of rituximab are largely unknown.

\section{Conclusion}

As a group, biologics clearly have a place in the management of adult arthritis. Pediatric data is limited, and further studies are needed. In the meantime, pediatric rheumatologists will continue to learn important safety and efficacy lessons from the adult rheumatology experience.

\section{Acknowledgments}

We would like to thank Marilynn Punaro and Virginia Pascual for their throughtful review of our manuscript; and Claudia Bracaglia for interpreting an Italian article. The authors report no conflicts of interest.

\section{References}

[No authors listed] 2007. Rituxan warning. FDA Consum, 41:3.

Abe T, Takeuchi T, Miyasaka N, et al. 2006. A multicenter, double-blind, randomized, placebo controlled trial of infliximab combined with low dose methotrexate in Japanese patients with rheumatoid arthritis. J Rheumatol, 33:37-44.

Abrams JR, Lebwohl MG, Guzzo CA, et al. 1999. CTLA4Ig-mediated blockade of T-cell costimulation in patients with psoriasis vulgaris. J Clin Invest, 103:1243-52.

Allantaz F, Chaussabel D, Stichweh D, et al. 2007. Blood leukocyte microarrays to diagnose systemic onset juvenile idiopathic arthritis and follow the response to IL-1 blockade. J Exp Med, 204:2131-44.

Anderson GM, Nakada MT, DeWitte M. 2004. Tumor necrosis factor-alpha in the pathogenesis and treatment of cancer. Curr Opin Pharmacol, 4:314-20.

Antoni C, Krueger GG, de Vlam K, et al. 2005a. Infliximab improves signs and symptoms of psoriatic arthritis: results of the IMPACT 2 trial. Ann Rheum Dis, 64:1150-7.

Antoni CE, Kavanaugh A, Kirkham B, et al. 2005b. Sustained benefits of infliximab therapy for dermatologic and articular manifestations of psoriatic arthritis: results from the infliximab multinational psoriatic arthritis controlled trial (IMPACT). Arthritis Rheum, 52:1227-36.

Armbrust W, Kamphuis SS, Wolfs TW, et al. 2004. Tuberculosis in a nineyear-old girl treated with infliximab for systemic juvenile idiopathic arthritis. Rheumatology (Oxford), 43:527-9.

Askling J, Fored CM, Baecklund E, et al. 2005a. Haematopoietic malignancies in rheumatoid arthritis: lymphoma risk and characteristics after exposure to tumour necrosis factor antagonists. Ann Rheum Dis, 64:1414-20. 
Askling J, Fored CM, Brandt L, et al. 2005b. Risks of solid cancers in patients with rheumatoid arthritis and after treatment with tumour necrosis factor antagonists. Ann Rheum Dis, 64:1421-6.

Askling J, Fored CM, Brandt L, et al. 2007. Time-dependent increase in risk of hospitalisation with infection among Swedish RA patients treated with TNF antagonists. Ann Rheum Dis, 66:1339-44.

Baecklund E, Iliadou A, Askling J, et al. 2006. Association of chronic inflammation, not its treatment, with increased lymphoma risk in rheumatoid arthritis. Arthritis Rheum, 54:692-701.

Baert F, Noman M, Vermeire S, et al. 2003. Influence of immunogenicity on the long-term efficacy of infliximab in Crohn's disease. $N$ Engl $J$ Med, 348:601-8.

Bendele AM, Chlipala ES, Scherrer J, et al. 2000. Combination benefit of treatment with the cytokine inhibitors interleukin-1 receptor antagonist and PEGylated soluble tumor necrosis factor receptor type I in animal models of rheumatoid arthritis. Arthritis Rheum, 43:2648-59.

Bendtzen K, Geborek P, Svenson M, et al. 2006. Individualized monitoring of drug bioavailability and immunogenicity in rheumatoid arthritis patients treated with the tumor necrosis factor alpha inhibitor infliximab. Arthritis Rheum, 54:3782-9.

Bennett CM, Rogers ZR, Kinnamon DD, et al. 2006. Prospective phase $1 / 2$ study of rituximab in childhood and adolescent chronic immune thrombocytopenic purpura. Blood, 107:2639-42.

Bernatsky S, Hudson M, Suissa S. 2007. Anti-rheumatic drug use and risk of serious infections in rheumatoid arthritis. Rheumatology (Oxford), 46:1157-60

Biester S, Deuter C, Michels H, et al. 2007. Adalimumab in the therapy of uveitis in childhood. Br J Ophthalmol, 91:319-24.

Billiau AD, Cornillie F, Wouters, C. 2002. Infliximab for systemic onset juvenile idiopathic arthritis: experience in 3 children. J Rheumatol, 29:1111-4.

Bluestone JA, St Clair EW, Turka LA. 2006. CTLA4Ig: bridging the basic immunology with clinical application. Immunity, 24:233-8.

Bongartz T, Sutton AJ, Sweeting MJ, et al. 2006. Anti-TNF antibody therapy in rheumatoid arthritis and the risk of serious infections and malignancies: systematic review and meta-analysis of rare harmful effects in randomized controlled trials. JAMA, 295:2275-85.

Brandt J, Khariouzov A, Listing J, et al. 2003. Six-month results of a doubleblind, placebo-controlled trial of etanercept treatment in patients with active ankylosing spondylitis. Arthritis Rheum, 48:1667-75.

Braun J, Davis J, Dougados M, et al. 2006. First update of the international ASAS consensus statement for the use of anti-TNF agents in patients with ankylosing spondylitis. Ann Rheum Dis, 65:316-20.

Breedveld FC, Weisman MH, Kavanaugh AF, et al. 2006. The PREMIER study: A multicenter, randomized, double-blind clinical trial of combination therapy with adalimumab plus methotrexate versus methotrexate alone or adalimumab alone in patients with early, aggressive rheumatoid arthritis who had not had previous methotrexate treatment. Arthritis Rheum, 54:26-37.

Bresnihan B, Alvaro-Gracia JM, Cobby M, et al. 1998. Treatment of rheumatoid arthritis with recombinant human interleukin-1 receptor antagonist. Arthritis Rheum, 41:2196-204.

[BTS] British Thoracic Society Standards of Care Committee. 2005. BTS recommendations for assessing risk and for managing Mycobacterium tuberculosis infection and disease in patients due to start anti-TNF-alpha treatment. Thorax, 60:800-5.

Brown SL, Greene MH, Gershon SK, et al. 2002. Tumor necrosis factor antagonist therapy and lymphoma development: twenty-six cases reported to the Food and Drug Administration. Arthritis Rheum, 46:3151-8.

Brulhart L, Ciurea A, Finckh A, et al. 2006. Efficacy of B cell depletion in patients with rheumatoid arthritis refractory to anti-tumour necrosis factor alpha agents: an open-label observational study. Ann Rheum Dis, 65:1255-7.

Burgos-Vargas R, Casasola-Vargas J, Gutierrez-Suarez R, et al. 2007. Efficacy, safety, and tolerability of infliximab in juvenile-onset spondyloarthropathies (JO-SpA): results of the three-month, randomized, double-blind, placebo-controlled trial phase [abstract]. Arthritis Rheum, 56(suppl):S319.
Burgos-Vargas R, Rudwaleit M, Sieper J. 2002a. The place of juvenile onset spondyloarthropathies in the Durban 1997 ILAR classification criteria of juvenile idiopathic arthritis. International League of Associations for Rheumatology. J Rheumatol, 29:869-74.

Burgos-Vargas R, Vazquez-Mellado J, Pacheco-Tena C, et al. 2002b. A 26 week randomised, double blind, placebo controlled exploratory study of sulfasalazine in juvenile onset spondyloarthropathies. Ann Rheum Dis, 61:941-2.

Calin A, Dijkmans BA, Emery P, et al. 2004. Outcomes of a multicentre randomised clinical trial of etanercept to treat ankylosing spondylitis Ann Rheum Dis, 63:1594-600.

Campion GV, Lebsack ME, Lookabaugh J, et al. 1996. Dose-range and dose-frequency study of recombinant human interleukin-1 receptor antagonist in patients with rheumatoid arthritis. The IL-1Ra Arthritis Study Group. Arthritis Rheum, 39:1092-101.

Carmona L, Gomez-Reino JJ, Rodriguez-Valverde V, et al. 2005. Effectiveness of recommendations to prevent reactivation of latent tuberculosis infection in patients treated with tumor necrosis factor antagonists. Arthritis Rheum, 52:1766-72.

Carswell EA, Old LJ, Kassel RL, et al. 1975. An endotoxin-induced serum factor that causes necrosis of tumors. Proc Natl Acad Sci USA, $72: 3666-70$

Chadha T, Hernandez JE. 2006. Infliximab-related lupus and associated valvulitis: a case report and review of the literature. Arthritis Rheum, 55:163-6.

Cheifetz A, Mayer L. 2005. Monoclonal antibodies, immunogenicity, and associated infusion reactions. Mt Sinai J Med, 72:250-6.

Chen J, Liu C. 2006. Is sulfasalazine effective in ankylosing spondylitis? A systematic review of randomized controlled trials. J Rheumatol, 33:722-31.

Choy EH, Isenberg DA, Garrood T, et al. 2002. Therapeutic benefit of blocking interleukin- 6 activity with an anti-interleukin-6 receptor monoclonal antibody in rheumatoid arthritis: a randomized, doubleblind, placebo-controlled, dose-escalation trial. Arthritis Rheum, 46:3143-50

Cohen JD, Bournerias I, Buffard V, et al. 2007. Psoriasis induced by tumor necrosis factor-alpha antagonist therapy: a case series. J Rheumatol, 34:380-5.

Cohen S, Hurd E, Cush J, et al. 2002. Treatment of rheumatoid arthritis with anakinra, a recombinant human interleukin-1 receptor antagonist, in combination with methotrexate: results of a twenty-four-week, multicenter, randomized, double-blind, placebo-controlled trial. Arthritis Rheum, 46:614-24.

Cohen SB. 2004. The use of anakinra, an interleukin-1 receptor antagonist, in the treatment of rheumatoid arthritis. Rheum Dis Clin North Am, 30:365-80, vii.

Cohen SB, Emery P, Greenwald MW, et al. 2006. Rituximab for rheumatoid arthritis refractory to anti-tumor necrosis factor therapy: Results of a multicenter, randomized, double-blind, placebo-controlled, phase III trial evaluating primary efficacy and safety at twenty-four weeks. Arthritis Rheum, 54:2793-806.

Cohen SB, Moreland LW, Cush JJ, et al. 2004. A multicentre, double blind, randomised, placebo controlled trial of anakinra (Kineret), a recombinant interleukin 1 receptor antagonist, in patients with rheumatoid arthritis treated with background methotrexate. Ann Rheum Dis, 63:1062-8.

Crandall WV, Mackner LM. 2003 Infusion reactions to infliximab in children and adolescents: frequency, outcome and a predictive model. Aliment Pharmacol Ther, 17:75-84.

Curtis JR, Patkar N, Xie A, et al. 2007. Risk of serious bacterial infections among rheumatoid arthritis patients exposed to tumor necrosis factor alpha antagonists. Arthritis Rheum, 56:1125-33.

Dass S, Vital EM, Emery P. 2007. Development of psoriasis after B cell depletion with rituximab. Arthritis Rheum, 56:2715-18.

Davis JC Jr., Van Der Heijde D, Braun J, et al. 2003. Recombinant human tumor necrosis factor receptor (etanercept) for treating ankylosing spondylitis: a randomized, controlled trial. Arthritis Rheum, 48:3230-6.

De Bandt M, Sibilia J, Le Loet X, et al. 2005. Systemic lupus erythematosus induced by anti-tumour necrosis factor alpha therapy: a French national survey. Arthritis Res Ther, 7:R545-51. 
de Benedetti F, Massa M, Robbioni P, et al. 1991. Correlation of serum interleukin-6 levels with joint involvement and thrombocytosis in systemic juvenile rheumatoid arthritis. Arthritis Rheum, 34:1158-63.

De Marco G, Gerloni V, Pontikaki I, et al. 2007. [Long-term evaluation of infliximab in the treatment of persistently active juvenile idiopathic arthritis refractory to conventional therapy.]. Reumatismo, 59:50-6.

Dinarello CA. 1996. Biologic basis for interleukin-1 in disease. Blood, $87: 2095-147$

Dixon W, Silman A. 2006. Is there an association between anti-TNF monoclonal antibody therapy in rheumatoid arthritis and risk of malignancy and serious infection? Commentary on the meta-analysis by Bongartz et al. Arthritis Res Ther, 8:111.

Dixon WG, Symmons DP, Lunt M, et al. 2007. Serious infection following anti-tumor necrosis factor alpha therapy in patients with rheumatoid arthritis: Lessons from interpreting data from observational studies. Arthritis Rheum, 56:2896-904.

Dixon WG, Watson K, Lunt M, et al. 2006. Rates of serious infection, including site-specific and bacterial intracellular infection, in rheumatoid arthritis patients receiving anti-tumor necrosis factor therapy: results from the British Society for Rheumatology Biologics Register. Arthritis Rheum, 54:2368-76.

Doran MF, Crowson CS, Pond GR, et al. 2002. Frequency of infection in patients with rheumatoid arthritis compared with controls: a population-based study. Arthritis Rheum, 46:2287-93.

Edwards JC, Szczepanski L, Szechinski J, et al. 2004. Efficacy of B-celltargeted therapy with rituximab in patients with rheumatoid arthritis. $N$ Engl J Med, 350:2572-81.

Eisenberg SP, Evans RJ, Arend WP, et al. 1990. Primary structure and functional expression from complementary DNA of a human interleukin-1 receptor antagonist. Nature, 343:341-6.

El-Hallak M, Binstadt BA, Leichtner AM, et al. 2007. Clinical effects and safety of rituximab for treatment of refractory pediatric autoimmune diseases. J Pediatr, 150:376-82.

Elliott MJ, Maini RN, Feldmann M, et al. 1994. Randomised double-blind comparison of chimeric monoclonal antibody to tumour necrosis factor alpha (cA2) versus placebo in rheumatoid arthritis. Lancet, 344:1105-10.

Elliott MJ, Woo P, Charles P, et al. 1997. Suppression of fever and the acute-phase response in a patient with juvenile chronic arthritis treated with monoclonal antibody to tumour necrosis factor-alpha (cA2). Br J Rheumatol, 36:589-93.

Emery P, Fleischmann R, Filipowicz-Sosnowska A, et al. 2006. The efficacy and safety of rituximab in patients with active rheumatoid arthritis despite methotrexate treatment: results of a phase IIB randomized, double-blind, placebo-controlled, dose-ranging trial. Arthritis Rheum, 54:1390-400.

Feige U, Hu YL, Gasser J, et al. 2000. Anti-interleukin-1 and anti-tumor necrosis factor-alpha synergistically inhibit adjuvant arthritis in Lewis rats. Cell Mol Life Sci, 57:1457-70.

Feldmann M, Brennan FM, Williams RO, et al. 2004. The transfer of a laboratory based hypothesis to a clinically useful therapy: the development of anti-TNF therapy of rheumatoid arthritis. Best Pract Res Clin Rheumatol, 18:59-80.

Ferraro-Peyret C, Coury F, Tebib JG, et al. 2004. Infliximab therapy in rheumatoid arthritis and ankylosing spondylitis-induced specific antinuclear and antiphospholipid autoantibodies without autoimmune clinical manifestations: a two-year prospective study. Arthritis Res Ther, 6:R535-43.

Ferucci ED, Majka DS, Parrish LA, et al. 2005. Antibodies against cyclic citrullinated peptide are associated with HLA-DR4 in simplex and multiplex polyarticular-onset juvenile rheumatoid arthritis. Arthritis Rheum, 52:239-46.

Finckh A, Ciurea A, Brulhart L, et al. 2007. B cell depletion may be more effective than switching to an alternative anti-tumor necrosis factor agent in rheumatoid arthritis patients with inadequate response to antitumor necrosis factor agents. Arthritis Rheum, 56:1417-23.

Fishman D, Faulds G, Jeffery R, et al. 1998. The effect of novel polymorphisms in the interleukin-6 (IL-6) gene on IL-6 transcription and plasma IL-6 levels, and an association with systemic-onset juvenile chronic arthritis. J Clin Invest, 102:1369-76.
Fitzgerald AA, Leclercq SA, Yan A, et al. 2005. Rapid responses to anakinra in patients with refractory adult-onset Still's disease. Arthritis Rheum, 52:1794-803.

Fleischmann RM, Schechtman J, Bennett R, et al. 2003. Anakinra, a recombinant human interleukin-1 receptor antagonist (r-metHuIL-1 ra), in patients with rheumatoid arthritis: A large, international, multicenter, placebo-controlled trial. Arthritis Rheum, 48:927-34.

Fleischmann RM, Tesser J, Schiff MH, et al. 2006. Safety of extended treatment with anakinra in patients with rheumatoid arthritis. Ann Rheum Dis, 65:1006-12.

Foeldvari I, Nielsen S, Kummerle-Deschner J, et al. 2007. Tumor necrosis factor-alpha blocker in treatment of juvenile idiopathic arthritisassociated uveitis refractory to second-line agents: results of a multinational survey. J Rheumatol, 34:1146-50.

Franklin J, Lunt M, Bunn D, et al. 2006. Incidence of lymphoma in a large primary care derived cohort of cases of inflammatory polyarthritis. Ann Rheum Dis, 65:617-22.

Franklin JP, Symmons DP, Silman AJ, 2005. Risk of lymphoma in patients with RA treated with anti-TNFalpha agents. Ann Rheum Dis, 64:657-8.

Freim Wahl SG, Folvik MR, Torp SH. 2007. Progressive multifocal leukoencephalopathy in a lymphoma patient with complete remission after treatment with cytostatics and rituximab: case report and review of the literature. Clin Neuropathol, 26:68-73.

Furst DE, Cush J, Kaufmann S, et al. 2002. Preliminary guidelines for diagnosing and treating tuberculosis in patients with rheumatoid arthritis in immunosuppressive trials or being treated with biological agents. Ann Rheum Dis, 61 (Suppl 2):ii62-3.

Furst DE, Schiff MH, Fleischmann RM, et al. 2003. Adalimumab, a fully human anti tumor necrosis factor-alpha monoclonal antibody, and concomitant standard antirheumatic therapy for the treatment of rheumatoid arthritis: results of STAR (Safety Trial of Adalimumab in Rheumatoid Arthritis). J Rheumatol, 30:2563-71.

Fusconi M, Vannini A, Dall'aglio AC, et al. 2007. Etanercept and infliximab induce the same serological autoimmune modifications in patients with rheumatoid arthritis. Rheumatol Int, 28:47-9.

Gartlehner G, Hansen RA, Jonas BL, et al. 2006. The comparative efficacy and safety of biologics for the treatment of rheumatoid arthritis: a systematic review and metaanalysis. J Rheumatol, 33:2398-408.

Gartlehner G, Hansen RA, Jonas BL, et al. 2008. Biologics for the treatment of juvenile idiopathic arthritis: a systematic review and critical analysis of the evidence. Clin Rheumatol, 27:67-76.

Geborek P, Bladstrom A, Turesson C, et al. 2005. Tumour necrosis factor blockers do not increase overall tumour risk in patients with rheumatoid arthritis, but may be associated with an increased risk of lymphomas. Ann Rheum Dis, 64:699-703.

Genovese M, Breedveld FC, Emery P, et al. 2006. TNF inhibitors in rheumatoid arthritis patients previously treated with rituximab [abstract]. Arthritis Rheum, 54 (suppl):S329.

Genovese MC, Becker JC, Schiff M, et al. 2005. Abatacept for rheumatoid arthritis refractory to tumor necrosis factor alpha inhibition. $N$ Engl J Med, 353:1114-23.

Genovese MC, Cohen S, Moreland L, et al. 2004. Combination therapy with etanercept and anakinra in the treatment of patients with rheumatoid arthritis who have been treated unsuccessfully with methotrexate. Arthritis Rheum, 50:1412-9.

Genovese MC, Mease PJ, Thomson GT, et al. 2007. Safety and efficacy of adalimumab in treatment of patients with psoriatic arthritis who had failed disease modifying antirheumatic drug therapy. $J$ Rheumatol, 34:1040-50.

Gensler L, Davis JC Jr. 2006. Recognition and treatment of juvenile-onset spondyloarthritis. Curr Opin Rheumatol, 18:507-11.

Gerloni V, Pontikaki I, Gattinara M, et al. 2005. Efficacy of repeated intravenous infusions of an anti-tumor necrosis factor alpha monoclonal antibody, infliximab, in persistently active, refractory juvenile idiopathic arthritis: results of an open-label prospective study. Arthritis Rheum, 52:548-53. 
Goldberg SL, Pecora AL, Alter RS, et al. 2002. Unusual viral infections (progressive multifocal leukoencephalopathy and cytomegalovirus disease) after high-dose chemotherapy with autologous blood stem cell rescue and peritransplantation rituximab. Blood, 99:1486-8.

Gomez-Reino JJ, Carmona L, Valverde VR, et al. 2003. Treatment of rheumatoid arthritis with tumor necrosis factor inhibitors may predispose to significant increase in tuberculosis risk: a multicenter activesurveillance report. Arthritis Rheum, 48:2122-7.

Gottenberg JE, Guillevin L, Lambotte O, et al. 2005. Tolerance and short term efficacy of rituximab in 43 patients with systemic autoimmune diseases. Ann Rheum Dis, 64:913-20.

Grillo-Lopez AJ, White CA, Varns C, et al. 1999. Overview of the clinical development of rituximab: first monoclonal antibody approved for the treatment of lymphoma. Semin Oncol, 26:66-73.

Haibel H, Brandt HC, Song IH, et al. 2007. No efficacy of subcutaneous methotrexate in active ankylosing spondylitis: a 16-week open-label trial. Ann Rheum Dis, 66:419-21.

Hashkes PJ, Laxer RM. 2006. Update on the medical treatment of juvenile idiopathic arthritis. Curr Rheumatol Rep, 8:450-8.

Henrickson M, Reiff A. 2004. Prolonged efficacy of etanercept in refractory enthesitis-related arthritis. J Rheumatol, 31:2055-61.

Higashida J, Wun T, Schmidt S, et al. 2005. Safety and efficacy of rituximab in patients with rheumatoid arthritis refractory to disease modifying antirheumatic drugs and anti-tumor necrosis factor-alpha treatment $J$ Rheumatol, 32:2109-15.

Hopkins SJ, Meager A. 1988. Cytokines in synovial fluid: II. The presence of tumour necrosis factor and interferon. Clin Exp Immunol, 73:88-92.

Horneff G, Schmeling H, Biedermann T, et al. 2004. The German etanercept registry for treatment of juvenile idiopathic arthritis. Ann Rheum Dis, 63:1638-44.

Huang JL, Chen LC. 1998. Sulphasalazine in the treatment of children with chronic arthritis. Clin Rheumatol, 17:359-63.

Ilowite N, Reiff A, Rudge S, et al. 2006. A randomized, multi-center, blinded, placebo-controlled study with an open-label run-in period to evaluate anakinra in polyarticular-course juvenile rheumatoid arthritis [abstract]. Arthritis Rheum, 54(Suppl):S327-28.

Ilowite NT, Porras O, Reiff A, et al. 2003. A twelve-week open label safety and efficacy study of anakinra (Kineret) in juvenile rheumatoid arthritis [abstract]. Ann Rheum Dis, 62(suppl 1):87.

Imagawa T, Mori M, Takei S, et al. 2006. Efficacy and safety of tocilizumab, an anti-IL-6 receptor monoclonal antibody, in patients with polyarticular or oligoarticular onset juvenile idiopathic arthritis [abstract]. Arthritis Rheum, 54(suppl):S168.

Irigoyen PI, Olson J, Hom C, et al. 2004. Treatment of systemic onset juvenile rheumatoid arthritis with anakinra [abstract]. Arthritis Rheum, 50(suppl) S437.

Isaacs JD, Morgan AW, Strand V. 1999. Combination biologic therapy. Clin Exp Rheumatol, 17:S121-4.

Jiang Y, Genant HK, Watt I, et al. 2000. A multicenter, double-blind, doseranging, randomized, placebo-controlled study of recombinant human interleukin-1 receptor antagonist in patients with rheumatoid arthritis: radiologic progression and correlation of Genant and Larsen scores. Arthritis Rheum, 43:1001-9.

Jois RN, Masding A, Somerville M, et al. 2007. Rituximab therapy in patients with resistant rheumatoid arthritis: real-life experience. Rheumatology (Oxford), 46:980-2.

Kahn P, Weiss M, Imundo LF, et al. 2006. Favorable response to highdose infliximab for refractory childhood uveitis. Ophthalmology, 113:860-4 e2.

Kalliolias GD, Georgiou PE, Antonopoulos IA, et al. 2007. Anakinra treatment in patients with adult-onset Still's disease is fast, effective, safe and steroid sparing: experience from an uncontrolled trial Ann Rheum Dis, 66:842-3.

Kapetanovic MC, Larsson L, Truedsson L, et al. 2006. Predictors of infusion reactions during infliximab treatment in patients with arthritis. Arthritis Res Ther, 8:R131.
Katsicas MM, Russo RA. 2005. Use of infliximab in patients with systemic juvenile idiopathic arthritis refractory to etanercept. Clin Exp Rheumatol, 23:545-8.

Kaur N, Mahl TC. 2007. Pneumocystis jiroveci (carinii) pneumonia after infliximab therapy: a review of 84 cases. Dig Dis Sci, 52:1481-4.

Kavanaugh A, St Clair EW, McCune WJ, et al. 2000. Chimeric anti-tumor necrosis factor-alpha monoclonal antibody treatment of patients with rheumatoid arthritis receiving methotrexate therapy. J Rheumatol, $27: 841-50$.

Kesteman T, Yombi JC, Gigi J, et al. 2007. Listeria infections associated with infliximab: case reports. Clin Rheumatol, 26:2173-5.

Keystone EC. 2005. Safety of biologic therapies--an update. J Rheumatol Suppl, 74:8-12.

Keystone EC, Kavanaugh AF, Sharp JT, et al. 2004a. Radiographic, clinical, and functional outcomes of treatment with adalimumab (a human antitumor necrosis factor monoclonal antibody) in patients with active rheumatoid arthritis receiving concomitant methotrexate therapy: a randomized, placebo-controlled, 52-week trial. Arthritis Rheum, 50:1400-11.

Keystone EC, Schiff MH, Kremer JM, et al. 2004b. Once-weekly administration of $50 \mathrm{mg}$ etanercept in patients with active rheumatoid arthritis: results of a multicenter, randomized, double-blind, placebo-controlled trial. Arthritis Rheum, 50:353-63.

Kietz DA, Pepmueller PH, Moore TL. 2002. Therapeutic use of etanercept in polyarticular course juvenile idiopathic arthritis over a two year period. Ann Rheum Dis, 61:171-3.

Kimby E. 2005. Tolerability and safety of rituximab (MabThera). Cancer Treat Rev, 31:456-73.

Kimura Y, Pinho P, Walco G, et al. 2005. Etanercept treatment in patients with refractory systemic onset juvenile rheumatoid arthritis. $J$ Rheumatol, 32:935-42.

Kinder A, Stephens S, Mortimer N, et al. 2004. Severe herpes zoster after infliximab infusion. Postgrad Med $J, 80: 26$.

Klareskog L, van der Heijde D, de Jager JP, et al. 2004. Therapeutic effect of the combination of etanercept and methotrexate compared with each treatment alone in patients with rheumatoid arthritis: double-blind randomised controlled trial. Lancet, 363:675-81.

Kneitz C, Wilhelm M, Tony HP. 2004. Improvement of refractory rheumatoid arthritis after depletion of B cells. Scand J Rheumatol, 33:82-6.

Kone-Paut I, Retornaz K, Garnier JM, et al. 2007. Visceral leishmaniasis in a patient with systemic juvenile arthritis treated by IL-1RA agonist (Anakinra). Clin Exp Rheumatol, 25:119.

Kotter I, Wacker A, Koch S, et al. 2007. Anakinra in patients with treatmentresistant adult-onset still's disease: Four case reports with serial cytokine measurements and a review of the literature. Semin Arthritis Rheum, 37:189-97.

Kremer JM, Dougados M, Emery P, et al. 2005. Treatment of rheumatoid arthritis with the selective costimulation modulator abatacept: twelvemonth results of a phase iib, double-blind, randomized, placebocontrolled trial. Arthritis Rheum, 52:2263-71.

Kremer JM, Genant HK, Moreland LW, et al. 2006. Effects of abatacept in patients with methotrexate-resistant active rheumatoid arthritis: a randomized trial. Ann Intern Med, 144:865-76.

Kremer JM, Westhovens R, Leon M, et al. 2003. Treatment of rheumatoid arthritis by selective inhibition of T-cell activation with fusion protein CTLA4Ig. N Engl J Med, 349:1907-15.

Kroesen S, Widmer AF, Tyndall A, et al. 2003. Serious bacterial infections in patients with rheumatoid arthritis under anti-TNF-alpha therapy. Rheumatology (Oxford), 42:617-21.

Krumrey-Langkammerer M, Hafner R. 2001. Evaluation of the ILAR criteria for juvenile idiopathic arthritis. J Rheumatol, 28:2544-7.

Kuek A, Hazleman BL, Gaston JH, et al. 2006. Successful treatment of refractory polyarticular juvenile idiopathic arthritis with rituximab. Rheumatology (Oxford), 45:1448-9.

Kuemmerle-Deschner JB, Horneff G. 2007. Safety and efficacy of once weekly application of Etanercept in children with juvenile idiopathic arthritis. Rheumatol Int, 28:153-6. 
Lahdenne P, Vahasalo P, Honkanen V. 2003. Infliximab or etanercept in the treatment of children with refractory juvenile idiopathic arthritis: an open label study. Ann Rheum Dis, 62:245-7.

Lan JL, Chou SJ, Chen DY, et al. 2004. A comparative study of etanercept plus methotrexate and methotrexate alone in Taiwanese patients with active rheumatoid arthritis: a 12-week, double-blind, randomized, placebo-controlled study. J Formos Med Assoc, 103:618-23.

Leandro MJ, Cambridge G, Ehrenstein MR, et al. 2006. Reconstitution of peripheral blood B cells after depletion with rituximab in patients with rheumatoid arthritis. Arthritis Rheum, 54:613-20.

Leandro MJ, Edwards JC, Cambridge G. 2002. Clinical outcome in 22 patients with rheumatoid arthritis treated with B lymphocyte depletion. Ann Rheum Dis, 61:883-8.

Lehman TJ. 2007. The future of pediatric rheumatology: Many questions remain. Arthritis Rheum, 56:2815-16.

Lepore L, Marchetti F, Facchini S, et al. 2003. Drug-induced systemic lupus erythematosus associated with etanercept therapy in a child with juvenile idiopathic arthritis. Clin Exp Rheumatol, 21:276-7.

Lequerre T, Quartier P, Rosellini D, et al. 2008. Interleukin-1 receptor antagonist (Anakinra) treatment with patients with systemiconset juvenile idiopathic arthritis or adult onset Still's disease: preliminary experience in France. Ann Rheum Dis, 67:302-8.

Linsley PS, Brady W, Urnes M, et al. 1991. CTLA-4 is a second receptor for the B cell activation antigen B7. J Exp Med, 174:561-9.

Lipsky PE, van der Heijde DM, St Clair EW, et al. 2000. Infliximab and methotrexate in the treatment of rheumatoid arthritis. Anti-Tumor Necrosis Factor Trial in Rheumatoid Arthritis with Concomitant Therapy Study Group. N Engl J Med, 343:1594-602.

Listing J, Strangfeld A, Kary S, et al. 2005. Infections in patients with rheumatoid arthritis treated with biologic agents. Arthritis Rheum, $52: 3403-12$

Lovell D, Ruperto N, Jung L, et al. 2006a. Long-term efficacy and safety of adalimumab in children with juvenile rheumatoid arthritis (JRA): 48-week results [abstract]. Arthritis Rheum, 54(suppl):S329.

Lovell DJ. 2006. Update on treatment of arthritis in children: new treatments, new goals. Bull NYU Hosp Jt Dis, 64:72-6.

Lovell DJ, Giannini EH, Reiff A, et al. 2000. Etanercept in children with polyarticular juvenile rheumatoid arthritis. Pediatric Rheumatology Collaborative Study Group. N Engl J Med, 342:763-9.

Lovell DJ, Reiff A, Jones OY, et al. 2006b. Long-term safety and efficacy of etanercept in children with polyarticular-course juvenile rheumatoid arthritis. Arthritis Rheum, 54:1987-94.

Lovell DJ, Ruperto N, Prieur AM, et al. 2006c. assessment of open label co-stimulation blockade with abatacept in children and adolescents with active juvenile idiopathic arthritis (JIA) [abstract]. Arthritis Rheum, 54(Suppl):S326.

Lovell DJ, Ruperto N, Prieur AM, et al. 2007. Abatacept treatment of juvenile idiopathic arthritis (JIA): safety report [abstract]. Arthritis Rheum, 56(Suppl):S292.

Maini RN, Breedveld FC, Kalden JR, et al. 1998. Therapeutic efficacy of multiple intravenous infusions of anti-tumor necrosis factor alpha monoclonal antibody combined with low-dose weekly methotrexate in rheumatoid arthritis. Arthritis Rheum, 41:1552-63.

Maini RN, Taylor PC, Szechinski J, et al. 2006. Double-blind randomized controlled clinical trial of the interleukin-6 receptor antagonist, tocilizumab, in European patients with rheumatoid arthritis who had an incomplete response to methotrexate. Arthritis Rheum, $54: 2817-29$.

Manners PJ, Bower C. 2002. Worldwide prevalence of juvenile arthritis why does it vary so much? J Rheumatol, 29:1520-30.

Mariette X, Salmon D. 2003. French guidelines for diagnosis and treating latent and active tuberculosis in patients with RA treated with TNF blockers. Ann Rheum Dis, 62:791.

Marks SD, Patey S, Brogan PA, et al. 2005. B lymphocyte depletion therapy in children with refractory systemic lupus erythematosus. Arthritis Rheum, 52:3168-74.
Marzo-Ortega H, McGonagle D, Jarrett S, et al. 2005. Infliximab in combination with methotrexate in active ankylosing spondylitis: a clinical and imaging study. Ann Rheum Dis, 64:1568-75.

Matsubara T, Hasegawa M, Shiraishi M, et al. 2006. A severe case of chronic infantile neurologic, cutaneous, articular syndrome treated with biologic agents. Arthritis Rheum, 54:2314-20.

Matteucci P, Magni M, Di Nicola M, et al. 2002. Leukoencephalopathy and papovavirus infection after treatment with chemotherapy and anti-CD20 monoclonal antibody. Blood, 100:1104-5.

Mease PJ, Gladman DD, Ritchlin CT, et al. 2005. Adalimumab for the treatment of patients with moderately to severely active psoriatic arthritis: results of a double-blind, randomized, placebo-controlled trial. Arthritis Rheum, 52:3279-89.

Mease PJ, Goffe BS, Metz J, et al. 2000. Etanercept in the treatment of psoriatic arthritis and psoriasis: a randomised trial. Lancet, 356:385-90.

Minden K, Kiessling U, Listing J, et al. 2000. Prognosis of patients with juvenile chronic arthritis and juvenile spondyloarthropathy. $J$ Rheumatol, 27:2256-63.

Mohrbacher A. 2005. B cell non-Hodgkin's lymphoma: rituximab safety experience. Arthritis Res Ther, 7(Suppl 3):S19-25.

Moore J, Ma D, Will R, et al. 2004. A phase II study of Rituximab in rheumatoid arthritis patients with recurrent disease following haematopoietic stem cell transplantation. Bone Marrow Transplant, 34:241-7.

Mor A, Bingham C 3rd, Barisoni L, et al. 2005. Proliferative lupus nephritis and leukocytoclastic vasculitis during treatment with etanercept. $J$ Rheumatol, 32:740-3.

Moreland LW, Alten R, Van den Bosch F, et al. 2002. Costimulatory blockade in patients with rheumatoid arthritis: a pilot, dose-finding, double-blind, placebo-controlled clinical trial evaluating CTLA-4Ig and LEA29Y eighty-five days after the first infusion. Arthritis Rheum, 46:1470-9.

Moreland LW, Baumgartner SW, Schiff MH, et al. 1997. Treatment of rheumatoid arthritis with a recombinant human tumor necrosis factor receptor (p75)-Fc fusion protein. $N$ Engl J Med, 337:141-7.

Moreland LW, Schiff MH, Baumgartner SW, et al. 1999. Etanercept therapy in rheumatoid arthritis. A randomized, controlled trial. Ann Intern Med, 130:478-86.

Nishimoto N, Hashimoto J, Miyasaka N, et al. 2007. Study of active controlled monotherapy used for rheumatoid arthritis, an IL-6 inhibitor (SAMURAI): evidence of clinical and radiographic benefit from an $\mathrm{x}$ ray reader-blinded randomised controlled trial of tocilizumab. Ann Rheum Dis, 66:1162-7.

Nishimoto N, Yoshizaki K, Miyasaka N, et al. 2004. Treatment of rheumatoid arthritis with humanized anti-interleukin-6 receptor antibody: a multicenter, double-blind, placebo-controlled trial. Arthritis Rheum, 50:1761-9.

Norambuena RX, Mallol J, Rios MG, et al. 2007. Therapeutic effects of the anti-tumor necrosis factor monoclonal antibody, infliximab, in four children with refractory juvenile idiopathic arthritis. Allergol Immunopathol (Madr), 35:52-6.

Ogilvie EM, Fife MS, Thompson SD, et al. 2003. The $-174 \mathrm{G}$ allele of the interleukin-6 gene confers susceptibility to systemic arthritis in children: a multicenter study using simplex and multiplex juvenile idiopathic arthritis families. Arthritis Rheum, 48:3202-6.

Ogilvie EM, Khan A, Hubank M, et al. 2007. Specific gene expression profiles in systemic juvenile idiopathic arthritis. Arthritis Rheum, 56:1954-65.

Parodi E, Nobili B, Perrotta S, et al. 2006. Rituximab (anti-CD20 monoclonal antibody) in children with chronic refractory symptomatic immune thrombocytopenic purpura: efficacy and safety of treatment. Int J Hematol, 84:48-53.

Pascual V, Allantaz F, Arce E, et al. 2005. Role of interleukin-1 (IL-1) in the pathogenesis of systemic onset juvenile idiopathic arthritis and clinical response to IL-1 blockade. J Exp Med, 201:1479-86.

Peek R, Scott-Jupp R, Strike H, et al. 2006. Psoriasis after treatment of juvenile idiopathic arthritis with etanercept. Ann Rheum Dis, 65:1259.

Petty RE, Southwood TR, Manners P, et al. 2004. International League of Associations for Rheumatology classification of juvenile idiopathic arthritis: second revision, Edmonton, 2001. J Rheumatol, 31:390-2. 
Pijpe J, van Imhoff GW, Spijkervet FK, et al. 2005. Rituximab treatment in patients with primary Sjogren's syndrome: an open-label phase II study. Arthritis Rheum, 52:2740-50.

Pincus T, Stein CM. 1997. Why randomized controlled clinical trials do not depict accurately long-term outcomes in rheumatoid arthritis: some explanations and suggestions for future studies. Clin Exp Rheumatol, 15(Suppl 17):S27-38.

Pirard D, Arco D, Debrouckere V, et al. 2006. Anti-tumor necrosis factor alpha-induced psoriasiform eruptions: three further cases and current overview. Dermatology, 213:182-6.

Popa C, Leandro MJ, Cambridge G, et al. 2007. Repeated B lymphocyte depletion with rituximab in rheumatoid arthritis over 7 yrs. Rheumatology (Oxford), 46:626-30.

Prescott K, Costner M, Cohen S, et al. 2007. Tumor necrosis factor-alpha inhibitor associated ulcerative colitis. Am J Med Sci, 333:137-9.

Prince FH, Twilt M, Jansen-Wijngaarden NC, et al. 2007. Effectiveness of a once weekly double dose of etanercept in patients with juvenile idiopathic arthritis: a clinical study. Ann Rheum Dis, 66:704-5.

Quartier P, Brethon B, Philippet P, et al. 2001. Treatment of childhood autoimmune haemolytic anaemia with rituximab. Lancet, 358:1511-3.

Quartier P, Taupin P, Bourdeaut F, et al. 2003. Efficacy of etanercept for the treatment of juvenile idiopathic arthritis according to the onset type. Arthritis Rheum, 48:1093-101.

Quartuccio L, De Vita S. 2007. Interleukin 1 receptor antagonist therapy-induced thrombocytopenia in adult onset Still's disease. J Rheumatol, 34:892-3.

Quinn MA, Conaghan PG, O'Connor PJ, et al. 2005. Very early treatment with infliximab in addition to methotrexate in early, poor-prognosis rheumatoid arthritis reduces magnetic resonance imaging evidence of synovitis and damage, with sustained benefit after infliximab withdrawal: results from a twelve-month randomized, double-blind, placebo-controlled trial. Arthritis Rheum, 52:27-35.

Rajaraman RT, Kimura Y, Li S, et al. 2006. Retrospective case review of pediatric patients with uveitis treated with infliximab. Ophthalmology, 113:308-14

Ramos-Casals M, Brito-Zeron P, Munoz S, et al. 2007. Autoimmune diseases induced by tnf-targeted therapies: Analysis of 233 cases. Medicine (Baltimore), 86:242-51.

Rankin EC, Choy EH, Kassimos D, et al. 1995. The therapeutic effects of an engineered human anti-tumour necrosis factor alpha antibody (CDP571) in rheumatoid arthritis. Br J Rheumatol, 34:334-42.

Rao A, Kelly M, Musselman M, et al. 2007. Safety, efficacy, and immune reconstitution after rituximab therapy in pediatric patients with chronic or refractory hematologic autoimmune cytopenias. Pediatr Blood Cancer, 50:822-5.

Reiff A, Takei S, Sadeghi S, et al. 2001. Etanercept therapy in children with treatment-resistant uveitis. Arthritis Rheum, 44:1411-5.

Richards JC, Tay-Kearney ML, Murray K, et al. 2005. Infliximab for juvenile idiopathic arthritis-associated uveitis. Clin Experiment Ophthalmol, 33:461-8.

Rigby WF. 2007. Drug insight: different mechanisms of action of tumor necrosis factor antagonists-passive-aggressive behavior? Nat Clin Pract Rheumatol, 3:227-33.

Rooney M, David J, Symons J, et al. 1995. Inflammatory cytokine responses in juvenile chronic arthritis. Br J Rheumatol, 34:454-60.

Ruiz PJ, Masliah E, Doherty TA, et al. 2007. Cardiac death in a patient with adult-onset Still's disease treated with the interleukin 1 receptor inhibitor anakinra. Ann Rheum Dis, 66:422-3.

Ruperto N, Lovell DJ, Cuttica R, et al. 2007. A randomized, placebocontrolled trial of infliximab plus methotrexate for the treatment of polyarticular-course juvenile rheumatoid arthritis. Arthritis Rheum, 56:3096-106.

Russo RA, Katsicas MM, Zelazko M. 2002. Etanercept in systemic juvenile idiopathic arthritis. Clin Exp Rheumatol, 20:723-6.

Saint Marcoux B, De Bandt M. 2006. Vasculitides induced by TNFalpha antagonists: a study in 39 patients in France. Joint Bone Spine, 73:710-13.
Salliot C, Gossec L, Ruyssen-Witrand A, et al. 2007. Infections during tumour necrosis factor-alpha blocker therapy for rheumatic diseases in daily practice: a systematic retrospective study of 709 patients. Rheumatology (Oxford), 46:327-34.

Salomon B, Bluestone JA. 2001. Complexities of CD28/B7: CTLA-4 costimulatory pathways in autoimmunity and transplantation. Annu Rev Immunol, 19:225-52.

Sampaio-Barros PD, Costallat LT, Bertolo MB, et al. 2000. Methotrexate in the treatment of ankylosing spondylitis. Scand J Rheumatol, 29:160-2.

Sato K, Tsuchiya M, Saldanha J, et al. 1993. Reshaping a human antibody to inhibit the interleukin 6-dependent tumor cell growth. Cancer Res, 53:851-6.

Saurenmann RK, Levin AV, Rose JB, et al. 2006. Tumour necrosis factor alpha inhibitors in the treatment of childhood uveitis. Rheumatology (Oxford), 45:982-9.

Saxena N, Misra R, Aggarwal A. 2006. Is the enthesitis-related arthritis subtype of juvenile idiopathic arthritis a form of chronic reactive arthritis? Rheumatology (Oxford), 45:1129-32.

Schaller J, Kupfer C, Wedgwood RJ. 1969. Iridocyclitis in juvenile rheumatoid arthritis. Pediatrics, 44:92-100.

Scheinberg M, Hamerschlak N, Kutner JM, et al. 2006. Rituximab in refractory autoimmune diseases: Brazilian experience with 29 patients (2002-2004). Clin Exp Rheumatol, 24:65-9.

Schmeling H, Horneff G. 2004. Infliximab in two patients with juvenile ankylosing spondylitis. Rheumatol Int, 24:173-6.

Schmeling H, Horneff G. 2005. Etanercept and uveitis in patients with juvenile idiopathic arthritis. Rheumatology (Oxford), 44:1008-11.

Schneeweiss S, Setoguchi S, Weinblatt ME, et al. 2007. Anti-tumor necrosis factor alpha therapy and the risk of serious bacterial infections in elderly patients with rheumatoid arthritis. Arthritis Rheum, 56:1754-64.

Setoguchi S, Solomon DH, Weinblatt ME, et al. 2006. Tumor necrosis factor alpha antagonist use and cancer in patients with rheumatoid arthritis. Arthritis Rheum, 54:2757-64.

Settas LD, Tsimirikas G, Vosvotekas G, et al. 2007. Reactivation of pulmonary tuberculosis in a patient with rheumatoid arthritis during treatment with IL-1 receptor antagonists (anakinra). J Clin Rheumatol, 13:219-20.

Sicotte NL, Voskuhl RR. 2001. Onset of multiple sclerosis associated with anti-TNF therapy. Neurology, 57:1885-8

Siddiqui MA. 2007. The efficacy and tolerability of newer biologics in rheumatoid arthritis: best current evidence. Curr Opin Rheumatol, 19:308-13.

Smith JA, Thompson DJ, Whitcup SM, et al. 2005. A randomized, placebocontrolled, double-masked clinical trial of etanercept for the treatment of uveitis associated with juvenile idiopathic arthritis. Arthritis Rheum, 53:18-23.

Smolen JS, Beaulieu A, Rubbert-Roth A, et al. 2008. Effect of interleukin-6 receptor inhibition with tocilizumab in patients with rheumatoid arthritis (OPTION study): a double-blind, placebo-controlled, randomised trial. Lancet, 371:987-97.

Smolen JS, Keystone EC, Emery P, et al. 2007. Consensus statement on the use of rituximab in patients with rheumatoid arthritis. Ann Rheum Dis, 66:143-50.

Solal-Celigny P. 2006. Safety of rituximab maintenance therapy in follicular lymphomas. Leuk Res, 30 (Suppl 1):S16-21.

St Clair EW, van der Heijde DM, Smolen JS, et al. 2004. Combination of infliximab and methotrexate therapy for early rheumatoid arthritis: a randomized, controlled trial. Arthritis Rheum, 50:3432-43.

Steurer M, Clausen J, Gotwald T, et al. 2003. Progressive multifocal leukoencephalopathy after allogeneic stem cell transplantation and posttransplantation rituximab. Transplantation, 76:435-6.

Tanaka Y, Yamamoto K, Takeuchi T, et al. 2007. A multicenter phase I/II trial of rituximab for refractory systemic lupus erythematosus. Mod Rheumatol, 17:191-7.

Tanno M, Nakamura I, Kobayashi S, et al. 2006. New-onset demyelination induced by infliximab therapy in two rheumatoid arthritis patients. Clin Rheumatol, 25:929-33. 
Taylor PC, Steuer A, Gruber J, et al. 2004. Comparison of ultrasonographic assessment of synovitis and joint vascularity with radiographic evaluation in a randomized, placebo-controlled study of infliximab therapy in early rheumatoid arthritis. Arthritis Rheum, 50:1107-16.

Thompson RC, Dripps DJ, Eisenberg SP. 1992. Interleukin-1 receptor antagonist (IL-1ra) as a probe and as a treatment for IL-1 mediated disease. Int J Immunopharmacol, 14:475-80.

Thonhofer R, Gaugg M, Kriessmayr M, et al. 2005. Spontaneous remission of marginal zone B cell lymphoma in a patient with seropositive rheumatoid arthritis after discontinuation of infliximab-methotrexate treatment. Ann Rheum Dis, 64:1098-9.

Todd DJ, Costenbader KH, Weinblatt MT. 2007. Abatacept in the treatment of rheumatoid arthritis. Int J Clin Prac, 61:494-500.

Todd DJ, Helfgott SM. 2007. Serum sickness following treatment with rituximab. J Rheumatol, 34:430-3.

Tse SM, Burgos-Vargas R, Laxer RM. 2005. Anti-tumor necrosis factor alpha blockade in the treatment of juvenile spondylarthropathy. Arthritis Rheum, 52:2103-8.

Tsutsumi Y, Kanamori H, Mori A, et al. 2005. Reactivation of hepatitis B virus with rituximab. Expert Opin Drug Saf, 4:599-608.

Tubach F, Ravaud P, Salmon-Ceron D, et al. 2006. Emergence of Legionella pneumophila pneumonia in patients receiving tumor necrosis factoralpha antagonists. Clin Infect Dis, 43:e95-100.

Turesson C, Riesbeck K. 2004. Septicemia with Staphylococcus aureus, beta-hemolytic streptococci group B and G, and Escherichia coli in a patient with rheumatoid arthritis treated with a recombinant human interleukin 1 receptor antagonist (Anakinra). J Rheumatol, 31:1876.

Tynjala P, Lindahl P, Honkanen V, et al. 2007. Infliximab and etanercept in the treatment of chronic uveitis associated with refractory juvenile idiopathic arthritis. Ann Rheum Dis, 66:548-50.

van de Putte LB, Atkins C, Malaise M, et al. 2004. Efficacy and safety of adalimumab as monotherapy in patients with rheumatoid arthritis for whom previous disease modifying antirheumatic drug treatment has failed. Ann Rheum Dis, 63:508-16.

van de Putte LB, Rau R, Breedveld FC, et al. 2003. Efficacy and safety of the fully human anti-tumour necrosis factor alpha monoclonal antibody adalimumab (D2E7) in DMARD refractory patients with rheumatoid arthritis: a 12 week, phase II study. Ann Rheum Dis, 62:1168-77.

van den Berg WB. 2002. Is there a rationale for combined TNF and IL-1 blocking in arthritis? Clin Exp Rheumatol, 20:S21-5.

Van Den Bosch F, Kruithof E, Baeten D, et al. 2002. Randomized doubleblind comparison of chimeric monoclonal antibody to tumor necrosis factor alpha (infliximab) versus placebo in active spondylarthropathy. Arthritis Rheum, 46:755-65.

van der Heijde D, Da Silva JC, Dougados M, et al. 2006a. Etanercept 50 $\mathrm{mg}$ once weekly is as effective as $25 \mathrm{mg}$ twice weekly in patients with ankylosing spondylitis. Ann Rheum Dis, 65:1572-7.

van der Heijde D, Dijkmans B, Geusens P, et al. 2005. Efficacy and safety of infliximab in patients with ankylosing spondylitis: results of a randomized, placebo-controlled trial (ASSERT). Arthritis Rheum, 52:582-91.

van der Heijde D, Kivitz A, Schiff MH, et al. 2006b. Efficacy and safety of adalimumab in patients with ankylosing spondylitis: results of a multicenter, randomized, double-blind, placebo-controlled trial. Arthritis Rheum, 54:2136-46.

van Ede A, den Broeder A, Wagenaar M, et al. 2007. Etanercept-related extensive pulmonary nodulosis in a patient with rheumatoid arthritis. $J$ Rheumatol, 34:1590-2.

Vasques Godinho FM, Parreira Santos, MJ and Canas da Silva, J 2005. Refractory adult onset Still's disease successfully treated with anakinra. Ann Rheum Dis, 64:647-8.

Vazquez-Cobian LB, Flynn T, Lehman TJ. 2006. Adalimumab therapy for childhood uveitis. J Pediatr, 149:572-5.

Verbsky JW, White AJ. 2004. Effective use of the recombinant interleukin 1 receptor antagonist anakinra in therapy resistant systemic onset juvenile rheumatoid arthritis. J Rheumatol, 31:2071-5.
Verschueren K, Van Essche E, Verschueren P, et al. 2007. Development of sarcoidosis in etanercept-treated rheumatoid arthritis patients. Clin Rheumatol, 26:1969-71.

Wang J, Wiley JM, Luddy R, et al. 2005. Chronic immune thrombocytopenic purpura in children: assessment of rituximab treatment. J Pediatr, 146:217-21.

Weinblatt M, Comb, B, Covucci A, et al. 2006. Safety of the selective costimulation modulator abatacept in rheumatoid arthritis patients receiving background biologic and nonbiologic disease-modifying antirheumatic drugs: A one-year randomized, placebo-controlled study. Arthritis Rheum, 54:2807-16.

Weinblatt M, Schiff M, Goldman A, et al. 2007. Selective costimulation modulation using abatacept in patients with active rheumatoid arthritis while receiving etanercept: a randomised clinical trial. Ann Rheum Dis, 66:228-34.

Weinblatt ME, Keystone EC, Furst DE, et al. 2003. Adalimumab, a fully human anti-tumor necrosis factor alpha monoclonal antibody, for the treatment of rheumatoid arthritis in patients taking concomitant methotrexate: the ARMADA trial. Arthritis Rheum, 48:35-45.

Weinblatt ME, Kremer JM, Bankhurst AD, et al. 1999. A trial of etanercept, a recombinant tumor necrosis factor receptor: $\mathrm{Fc}$ fusion protein, in patients with rheumatoid arthritis receiving methotrexate. N Engl J Med, 340:253-9.

Westhovens R, Yocum D, Han J, et al. 2006. The safety of infliximab, combined with background treatments, among patients with rheumatoid arthritis and various comorbidities: a large, randomized, placebocontrolled trial. Arthritis Rheum, 54:1075-86.

Willems M, Haddad E, Niaudet P, et al. 2006. Rituximab therapy for childhood-onset systemic lupus erythematosus. J Pediatr, 148:623-27.

Wolfe F, Caplan L, Michaud K. 2006. Treatment for rheumatoid arthritis and the risk of hospitalization for pneumonia: associations with prednisone, disease-modifying antirheumatic drugs, and anti-tumor necrosis factor therapy. Arthritis Rheum, 54:628-34.

Wolfe F, Michaud K. 2004. Lymphoma in rheumatoid arthritis: the effect of methotrexate and anti-tumor necrosis factor therapy in 18,572 patients. Arthritis Rheum, 50:1740-51.

Wolfe F, Michaud K. 2007a. Biologic treatment of rheumatoid arthritis and the risk of malignancy: Analyses from a large US observational study. Arthritis Rheum, 56:2886-95.

Wolfe F, Michaud K. 2007b. The effect of methotrexate and anti-tumor necrosis factor therapy on the risk of lymphoma in rheumatoid arthritis in 19,562 patients during 89,710 person-years of observation. Arthritis Rheum, 56:1433-9.

Woo P, Wilkinson N, Prieur AM, et al. 2005. Open label phase II trial of single, ascending doses of MRA in Caucasian children with severe systemic juvenile idiopathic arthritis: proof of principle of the efficacy of IL- 6 receptor blockade in this type of arthritis and demonstration of prolonged clinical improvement. Arthritis Res Ther, 7:R1281-8.

Yokota S, Imagawa T, Mori M, et al. 2008. Efficacy and safety of tocilizumab in patients with systemic-onset juvenile idiopathic arthritis: a randomised, double-blind, placebo-controlled, withdrawal phase III trial. Lancet, 371:998-1006.

Yokota S, Miyamae T, Imagawa T, et al. 2005. Therapeutic efficacy of humanized recombinant anti-interleukin-6 receptor antibody in children with systemic-onset juvenile idiopathic arthritis. Arthritis Rheum, 52:818-25.

Zhou H. 2005. Clinical pharmacokinetics of etanercept: a fully humanized soluble recombinant tumor necrosis factor receptor fusion protein. J Clin Pharmacol, 45:490-7.

Zink A, Strangfeld A, Schneider M, et al. 2006. Effectiveness of tumor necrosis factor inhibitors in rheumatoid arthritis in an observational cohort study: comparison of patients according to their eligibility for major randomized clinical trials. Arthritis Rheum, 54:3399-407.

Zwerina J, Hayer S, Tohidast-Akrad M, et al. 2004. Single and combined inhibition of tumor necrosis factor, interleukin-1, and RANKL pathways in tumor necrosis factor-induced arthritis: effects on synovial inflammation, bone erosion, and cartilage destruction. Arthritis Rheum, 50:277-90. 